\title{
Numerical Classification of "Mycobacterium" rhodochrous and Runyon's Group IV Mycobacteria
}

\author{
M. GOODFELLOW, A. FLEMING, and M. J. SACKIN \\ Department of Microbiology, The Medical School, University of Newcastle, Newcastle \\ upon Tyne, NE $17 R U$, England; \\ M. R. C. Microbial Systematics Research Unit, Leicester University, Leicester, England
}

\begin{abstract}
A numerical classification study was carried out on 129 strains representing "Mycobacterium" rhodochrous, Runyon's Group IV mycobacteria, and other related taxa. Cultures of these strains were examined for 170 characters, and the resultant data have been analyzed by computer. Similarity coefficients were calculated in two ways: by the first, negative and positive matches were scored, and in the second, positive similarities only; in each case. clustering was with the average linkage cluster analysis technique. The two coefficients of association yielded the same four clusters, and, with a single exception, substantially the same subgroups. The three homogeneous clusters corresponded to: (i) " $M$." rhodochrous, (ii) Nocardia pellegrino, and (iii) Mycobacterium Group IV. Twenty-three named mycobacteria were recovered in seven subgroups, six of which were equated with the established taxa $M$. borstelense, $M$. chitae, $M$. gallinarum, $M$. fortuitum, $M$. smegmatis, and $M$. vaccae. Characters were abstracted from the data and used for the identification of clusters and subgroups.
\end{abstract}

The generic location of "Mycobacterium" rhodochrous has always been uncertain $(8,9)$. Gordon (7) considered the properties of this taxon to be intermediate between those of Nocardia and Mycobacterium but different from Corynebacterium. The results of an extensive numerical taxonomic study, however, have shown that "M." rhodochrous strains form a taxon which occupies a similar rank to clusters which contain nocardiae, actinomadurae, and oerskoviae (6). Since no corresponding large-scale study had been done comparing rapidly growing mycobacteria and " $M$." rhodochrous, this name was retained for convenience, but its temporary nature was recognized. This taxon is included in the newly proposed genus Gordona (27) but only on the basis of evidence collected from six named strains. Jensenia canicruria is now considered to belong to the "M." rhodochrous group (6), so that if this taxon is to be a genus, Gordona is a later synonym of the earlier name Jensenia. The primary aim of this study was to compare representative strains of fast-growing mycobacteria with strains drawn from the "M." rhodochrous complex.
Many new species have been described since Runyon classified atypical mycobacteria into four groups (17). New species have been proposed particularly commonly in Group IV (1-3, 16, 23-25). Although some comparative taxonomic work has been done $(11,12,24$, 28 ), it is by no means clear whether the differences between some of these new taxa merit their separation into species. A second purpose of this paper was to establish the quantitative relationships between the species of fast-growing mycobacteria.

All the test organisms were examined for characters which had been included in a previous analysis (6). Although the test selection was intended to be unbiased, it was not known whether characters which had been found useful in the classification of nocardioform bacteria would be relevant in studying mycobacteria. It has been shown that a large number of inappropriate tests can introduce levels of "noise" sufficient to obscure differences between taxa (5). To ensure against such a possibility, the results of a single coefficient of association should not always be accepted uncritically. In the present study, similarity 
TABLE 1. Strains examined

\begin{tabular}{|c|c|c|c|c|}
\hline & Strain & Laboratory no. ${ }^{\alpha}$ & Source & Comment \\
\hline M29 & Mycobacterium abscessus & LA 948 & ATCC 19977 & Type strain \\
\hline M88 & M. abscessus & ATCC 19977 & ATCC 19977 & Type strain \\
\hline M12 & M. aurum & NCTC 10437 & ATCC 23366 & Type strain; Biotype 1 \\
\hline M13 & M. aurum & NCTC 10438 & NCTC 10438 & Biotype 1 \\
\hline M15 & M. aurum & NCTC 10440 & NCTC 10440 & Biotype 11 \\
\hline M155 & M. borstelense & R. Bönicke, SN $281^{b}$ & ATCC 19235 & Type strain \\
\hline M90 & $\begin{array}{l}M . \text { borstelense subsp. } \\
\text { niacinogenes }\end{array}$ & ATCC 19237 & R. Bönicke SN 286 & Type strain \\
\hline M156 & $\begin{array}{l}M . \text { borstelense subsp. } \\
\text { niacinogenes }\end{array}$ & R. Bönicke SN 286 & ATCC 19237 & Type strain \\
\hline M157 & $\begin{array}{l}M . \text { borstelense subsp. } \\
\text { niacinogenes }\end{array}$ & R. Bönicke SN 284 & ATCC 19537 & \\
\hline M91 & M. butyricum & ATCC 19979 & ATCC 19979 & \\
\hline M25 & M. chitae & NCTC 10485 & ATCC 19627 & Type strain \\
\hline M26 & M. chitae & NCTC 10495 & NCTC 10495 & \\
\hline M73 & M. chitae & $\begin{array}{l}\text { M. Tsukamura } \\
2050\end{array}$ & ATCC 19629 & \\
\hline M74 & M. chitae & M. Tsukamura 2050 & ATCC 19630 & \\
\hline M92 & M. diernhoferi & ATCC 19340 & R. Bönicke SN 1418 & Type strain \\
\hline M158 & M. diernhoferi & R. Bönicke SN 1418 & ATCC 19340 & Type strain \\
\hline M159 & M. diernhoferi & R. Bönicke SN 1403 & R. Bönicke SN 1043 & \\
\hline MI60 & M. diernhoferi & R. Bönicke SN 1425 & ATCC 19344 & \\
\hline M61 & M. fortuitum & 1. Baess ${ }^{d}$ F 656 & & Froman, $70 \mathrm{M}$. minetti) \\
\hline M62 & M. fortuitum & 1. Baess F 141 & ATCC 9820 & \\
\hline M93 & M. fortuitum & ATCC 6841 & & \\
\hline M79 & M. gallinarum & M. Tsukamura 2506 & ATCC 19710 & Type strain \\
\hline M80 & M. gallinarum & M. Tsukamura 2507 & ATCC 19711 & \\
\hline M38 & M. giae & LA 82 & ATCC 11440 & \\
\hline M94 & M. lacticola & ATCC 19980 & & \\
\hline M95 & $M$. minetti & ATCC 19542 & & \\
\hline M16 & M. parafortuitum & NCTC 10410 & & \\
\hline M17 & $M$. parafortuitum & NCTC 10411 & ATCC 19686 & Type strain \\
\hline M53 & $M$. parafortuitum & LA 2488 & ATCC 19688 & \\
\hline M77 & M. parafortuitum & M. Tsukamura 305 & & \\
\hline M78 & M. parafortuitum & M. Tsukamura 2590 & & \\
\hline M96 & $M$. parafortuitum & ATCC 19686 & & Type strain \\
\hline M97 & M. parafortuitum & ATCC 19687 & & \\
\hline M6 & $M$. peregrinum & NCTC 10264 & ATCC 14467 & Type strain \\
\hline M49 & M. platypoecilus & LA 1258 & & \\
\hline M60 & M. phlei & I. Baess F 89 & & \\
\hline M98 & M. phlei & ATCC 11758 & & \\
\hline M83 & M. piscium & M. Tsukamura 08006 & & \\
\hline M50 & $M$. ranae & LA 1260 & & \\
\hline M51 & $M$. ranae & LA 17 & & \\
\hline M99 & M. rhodochrous & ATCC 13808 & R. E. Gordon, 372 & \\
\hline $\mathrm{N} 424$ & $M$, rhodochrous & J. Norris ${ }^{e}$ & & \\
\hline M7 & $M$. runyonii & NCTC 10269 & ATCC 14472 & Type strain \\
\hline M100 & $M$. runyonii & ATCC 14472 & & Type strain \\
\hline M32 & M. salmoniphilum & LA 1263 & ATCC 13756 & Type strain \\
\hline M21 & M. smegmatis & NCTC 334 & & \\
\hline M57 & M. smegmatis & I. Baess F 2 I & ATCC 607 & \\
\hline M59 & M. smegmatis & I. Baess F 87 & & \\
\hline M63 & M. smegmatis & I. Baess 108 & & \\
\hline M101 & M. smegmatis & ATCC 14468 & & Suggested neotype \\
\hline M40 & M. thamnopheos & LA 62 & & \\
\hline M84 & M. thamnopheos & M. Tsukamura 20001 & & \\
\hline M11 & $M$. thermoresistibile & NCTC 10409 & ATCC 19527 & Type strain \\
\hline M75 & $M$. thermoresistibile & M. Tsukamura 1002 & ATCC 19528 & \\
\hline M76 & M. thermoresistibile & M. Tsukamura 1028 & ATCC 19529 & \\
\hline M36 & $M$. vaccae & LA 2303 & & \\
\hline
\end{tabular}


TABLE 1.-Continued

\begin{tabular}{|c|c|c|c|c|}
\hline & Strain & Laboratory no. ${ }^{a}$ & Source & Comment \\
\hline M37 & M. vaccae & $\begin{array}{l}\text { LA 2304; R. } \\
\quad \text { Bönicke SN } 920\end{array}$ & ATCC 15483 & Type strain \\
\hline M56 & M. vaccae & $\begin{array}{l}\text { I. Baess } 663 ; \mathrm{R} \text {. } \\
\text { Bönicke SN } 920\end{array}$ & ATCC 15483 & Type strain \\
\hline M161 & M. vaccae & R. Bönicke SN 920 & ATCC 15483 & Type strain \\
\hline M162 & M. vaccae & R. Bönicke SN 911 & & \\
\hline M163 & M. vaccae & R. Bönicke SN 962 & & \\
\hline M102 & $M . \mathrm{sp}$. & ATCC 607 & & \\
\hline M106 & $M . \mathrm{sp}$. & ATCC 23001 & & \\
\hline M110 & $M$. sp. & ATCC 23005 & & \\
\hline M111 & $M$. sp. & ATCC 23006 & & \\
\hline M112 & M. sp. & ATCC 23007 & & \\
\hline M113 & M. sp. & ATCC 23008 & & \\
\hline M114 & $M$. sp. & ATCC 23009 & & \\
\hline N324 & Nocardia pellegrino & ATCC 15998 & & \\
\hline N325 & N. pellegrino & $\begin{array}{l}\text { G. Castelnuova, }{ }^{f} \\
\text { strain } 906 \mathrm{~B}\end{array}$ & & \\
\hline N326 & N. pellegrino & G. Castelnuovo 107 & & \\
\hline N327 & N. pellegrino & G. Castelnuova 906 & & \\
\hline N420 & N. pellegrino & $\begin{array}{l}\text { A. } \text { Tacquet }^{B} \\
\text { strain } 906\end{array}$ & & \\
\hline N421 & N. pellegrino & A. Tacquet 906 B & & \\
\hline $\mathrm{N} 422$ & N. pellegrino & A. Tacquet 107 & & \\
\hline N423 & N. pellegrino & A. Tacquet 330 & & \\
\hline N361 & N. rubra & M. Tsukamura M 1 & & \\
\hline N362 & N. rubra & M. Tsukamura M 75 & & \\
\hline N363 & N. rubra & M. Tsukamura M 192 & & \\
\hline
\end{tabular}

${ }^{a}$ ATCC, American Type Culture Collection, Rockville, Md., U.S.A.; LA, Institut d'Hygiene, Lausanne, Switzerland; NCTC, National Collection of Type Cultures, London, England.

${ }^{o}$ R. Bonicke, Institut fur experimentelle Biologie und Medizin, Borstel, Germany.

${ }^{c}$ M. Tsukamura, National Sanatorium, Chubu Chest Hospital, Obu, Aichi-ken 474, Japan.

${ }^{d}$ I. Baess, Statens Seruminstitut, Copenhagen, Denmark.

e"Shell" Research, Ltd., Sittingbourne, England.

' Instituto Superiore di Sanita, Roma.

Institut Pasteur, Lille.

coefficients were calculated by counting positive similarities only (18) as well as by scoring positive and negative matches $(21)$, thereby making it possible to detect cluster formation due to negative matches.

Although the main purpose of this work was classification, the taxa formed were examined, and characters were extracted from the data to facilitate the identification of the taxa.

\section{MATERIALS AND METHODS}

Strains. Sixty-nine strains of mycobacteria and ten strains of nocardiae were examined. The mycobacteria were received bearing 24 specific names and included, where possible, type or neotype strains. The name, source, and laboratory number of each organism are listed in Table 1.

Previously data had been collected on 50 " $M$.' rhodochrous strains and marker cultures representing the genera Arthrobacter, Cellulomonas, and Corynebacterium. Details about these strains, including the results of the previous classification, are given in Table 2.

Maintenance of strains. The cultures were maintained at room temperature on two media: (i) modified Sauton's agar (14) and (ii) yeast extract agar (6).

Collection of data. All strains were examined for purity, gram-stained, and then tested for the 170 unit characters (Table 3 ). The resultant data were pooled with those previously collected on the "M." rhodochrous and marker strains.

Details of the media and methods used have been described previously (6). Test media were inoculated from cultures grown for 7 days on yeast extract-agar. The tests were incubated at $37 \mathrm{C}$ and read after 7 and 14 days. The nutritional and inhibition studies, and some of the biochemical tests, were carried out in divided polysty rene Replidishes. These dishes, containing 25 separate compartments, were inoculated with a simple multipoint inoculator (20). The use of this technique allows data to be collected quickly and also results in a $50 \%$ saving in the unit cost per test. The hydrolysis tests involved the measurement of zones of clearing and were carried out in petri dishes. Tests were repeated only when the results were inconclusive. 
TABLE 2. Representatives of the "Mycobacterium" rhodochrous cluster, and marker strains, included in the computer analyses ${ }^{a}$

Subgroup 14 B

N30 "M." rhodochrous; R. E. Gordon, Rutgers University, New Brunswick, N.J., USA, strain A 12974. ATCC 12974.

N3I "M." rhodochrous strain R. E. Gordon W 21

Subgroup $14 \mathrm{C}$

N27 "M." rhodochrous CCM 278

N54 "M." rhodochrous ATCC 13808

N55 "M." rhodochrous strain R. E. Gordon 817

N61 "M." rhodochrous strain R. E. Gordon W 3408. ATCC 4273

N73 "M." rhodochrous; S. T. Williams, University of Liverpool, strain E 40

N75 " $M$." rhodochrous LA 1609

N83 "M." rhodochrous strain S. T. Williams E 40

N111 "M." rhodochrous strain R. E. Gordon 562

N112 "M." rhodochrous; V. B. D. Skerman, University of Queensland, strain 121

N128 "M." rhodochrous CBS 196.57

N240 " $M$." rhodochrous NCTC 8571

N239 "M." rhodochrous NCTC 8727

Subgroup 14 D

N4 "M." rhodochrous NCIB 9664

N11 “M." rhodochrous NCIB 9158. ATCC 4277

N12 " $M$." rhodochrous NCIB 9159

N25 "M." rhodochrous CCM 279

N57 "M." rhodochrous strain R. E. Gordon 1293S

N58 “M." rhodochrous strain R. E. Gordon 1257

N59 "M." rhodochrous strain R. E. Gordon 1240

N60 " $M$." rhodochrous strain R. E. Gordon 1293 R

N63 "M." rhodochrous strain R. E. Gordon 463

N64 " $M$." rhodochrous strain R. E. Gordon 417

N65 "M." rhodochrous strain R. E. Gordon A 7698. ATCC 7698

N84 " $M$." rhodochrous strain S. T. Williams E 41

N108 " $M$." rhodochrous strain R. E. Gordon A 4277. ATCC 4277

N143 “M." rhodochrous; M. Turner, University of Nottingham, England, strain 29

Subgroup $14 \mathrm{E}$

N7 - "M." rhodochrous NCIB 10027

N10 "M." rhodochrous NCIB 9557. ATCC 12674

N66 " $M$." rhodochrous NCTC 8139

N125 "M." rhodochrous CBS 331.61

N135 "M." rhodochrous; J. Antheunisse, Landbouwhogeschool, Wageningen, Holland, strain AC 338

N146 "M." rhodochrous strain M. Turner 39

Subgroup $14 \mathrm{~F}$

N147 Corynebacterium sp. strain M. Turner 65

Ni54 Arthrobacter sp. strain M. Turner X 55

N155 A. sp. strain M. Turner X 56

Subgroup $14 \mathrm{G}$

N170 A. sp.; J. Went, ITBON, 11 Kemperbergerweg, Arnhem, Holland, strain 180

N176 $A$. sp. strain J Went 1845

N253 Nocardia sp., T. Cross, University of Bradford, England, strain CUB 193

N254 N. sp. strain T. Cross 194

Subgroup $14 \mathrm{H}$

N138 N. sp. strain J. Antheunisse R 481

N139 N. sp. strain J. Antheunisse R 494

Marker strains

N291 Arthrobacter globiformis NCIB 8602. ATCC 4336

N295 A. simplex NCIB 8929. ATCC 6946

N297 A.tumescens NCIB 8914. ATCC 6947

N296 A. ureafaciens NCIB 7811. ATCC 7562 Type strain

N293 Cellulomonas biazotea NCIB 8077. ATCC 486

N294 Mycobacterium fortuitum ATCC 6841

N41 Nocardia calcarea NCIB 8863. ATCC 19369

${ }^{a}$ CBS, Centraalbureau voor Schimmelcultures, Baarn, Netherlands; CCM, Czechoslovak Collection of Microorganisms, J. E. Purkyne University, Brno; NCIB, National Collection of Industrial Bacteria, Aberdeen, Scotland; see also footnote $a$ of Table 1 . 
Coding of characters. Most of the characters existed in one of two mutually exclusive states and were readily scored plus $(+)$ or minus $(-)$. Multistate characters were coded in one of two ways. Qualitative multistate characters, such as pigmentation and colony elevation, were scored plus $(+)$ for the character state shown and minus $(-)$ for the alternatives. Quantitative multistate characters, for example tolerance to $\mathrm{pH}$ and degree of acid-fastness, were coded by the additive method of Sokal and Sneath (22). The results of all the tests were entered onto standard IBM punched cards.

Computer analyses. Similarity coefficients were calculated by using the method of Sokal and Michener (21), which counts negative matches, and secondly by the method which scores only positive similarities (18). Thus, where $S$ is the similarity coefficient (usually expressed as a percentage), $N s p$ and $N s n$ the number of positive and negative similarities respectively, and $N d$ the number of nonmatching characters, then using Sokal and Michener's method, $S=(N$ $s p+N s n) /(N s p+N s n+N d)$, and, according to Sneath, $S=N s p /(N s p+N d)$.

Sorted similarity matrices were obtained by using the unweighted average linkage cluster analysis technique. The computation was carried out on an ICL 4130 computer at Leicester University.

\section{RESULTS}

Examination of matching data, including negative matches. In the matching coefficient analysis, 122 of the 129 organisms were grouped into one of four clusters defined at the $80 \%$ level (Fig. 1). One of the large clusters (cluster 2) corresponds to the fast-growing mycobacteria, and the second (cluster 14) to " $M$." rhodochrous. These two clusters join at the $67 \% S$ level. A third well-defined cluster (cluster 1) consists mainly of Nocardia pellegrino strains, but it also includes strains of Nocardia rubra and " $M$." rhodochrous. Cluster 3 was ill-defined and contains strains received as arthrobacters, cory nebacteria, and nocardiae.

The two larger clusters can readily be divided into subgroups at or above the $85 \%$ level. There was good overall agreement in the composition of the "M." rhodochrous subgroups between this analysis and the previous one (6). This was not unexpected because the battery of unit characters used was very similar. The only difference was that the enlarged $N$. pellegrino taxon now formed a distinct cluster which coalesced with cluster 14 at the $68 \%$ level.

Cluster 2 consists of four subgroups. The largest, $2 \mathrm{~A}$, is heterogeneous and contains 21 strains carrying nine specific names. At the $90 \%$ level, strains of $M$. abscessus, $M$. peregrinum, $M$. piscium, and $M$. runyonii unite to form a tight nucleus to the group. The other named strains included in the subgroup are $M$. borstelense, $M$. chitae, $M$. gallinarum, $M$. thamnopheos, and $M$. thermoresistibile.

Subgroup $2 \mathrm{~B}$ is the most homogeneous and contains 24 strains. Mycobacterium aurum, $M$. parafortuitum, and $M$. vaccae cluster above the $90 \%$ level. Mycobacterium diernhoferi and two strains received as Mycobacterium sp. join this nucleus at a similarity of $87 \%$.

Subgroup $2 \mathrm{C}$ is also homogeneous but consists of only six strains. Three of these were received as $M$. fortuitum, the others as $M$. minetti, M. platypoecilus, and M. salmoniphilum.

The final subgroup, 2D, contains ten strains. Four were received as $M$. smegmatis; the remaining named strains are $M$. butyricum, $M$. lacticola, $M$. phlei, and $M$. ranae.

There were seven unplaced organisms. These included three marker strains named Arthrobacter globiformis, A. ureafaciens, and Cellulomonas biazotea, and strains of $M$. thamnopheos and $M$. thermoresistibile.

Examination of the data counting positive matches only. The sorted similarity matrix (Fig. 2) was compiled from data counting positive matches only. By comparing this similarity matrix with the previous one, it can be seen that the four clusters are recovered. However, when only positive similarities are counted, the clusters are defined at a lower level of similarity.

The only significant difference between the results of the two analyses is in the composition of subgroup $2 \mathrm{~A}$. In the second analysis, strains of $M$. borstelense, $M$. chitae, and $M$. gallinarum are found in separate subgroups, leaving subgroup $2 \mathrm{~A}$ as a small, homogeneous group which shares a high phenetic similarity with subgroup $2 C$. The similarity between subgroups $2 \mathrm{C}$ and $2 \mathrm{~B}$ is equally high. In the second analysis, a strain of $M$. runyonii and one of $M$. peregrinum are found in subgroup $2 \mathrm{C}$. These results suggest that, in the first analysis, some of the mycobacteria, particularly the slower growing strains, were grouped into subgroup $2 \mathrm{~A}$ by virtue of high negative matching. The dendrograms derived by counting positive matches were then reproduced (Fig. 3 and 4). Only the clusters and subgroups defined in this way are considered further.

Identification of clusters. Certain features are common to almost all of the strains. The organisms are aerobic, gram-positive, nonmotile, oxidase negative, and grow on yeast extract-agar at $p \mathrm{H} 6$ to 10 and at temperatures between 25 and $35 \mathrm{C}$. They hydrolyze Tween 
TABLE 3. Unit characters

\begin{tabular}{|c|c|c|c|}
\hline Characters & No. of states & Characters & No. of states \\
\hline 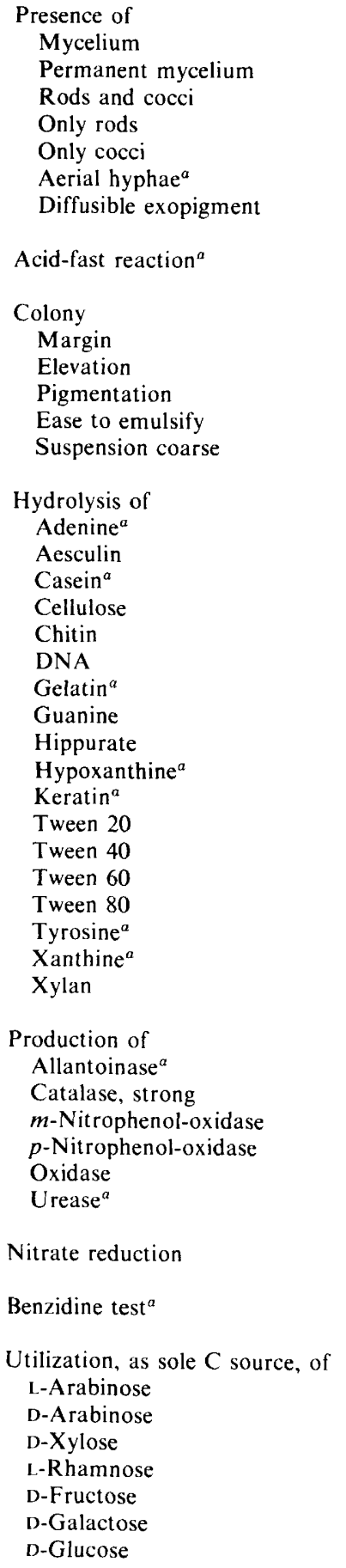 & $\begin{array}{l}3 \\
2 \\
3 \\
2 \\
2 \\
2 \\
3 \\
2 \\
2 \\
3 \\
3 \\
2 \\
2 \\
2 \\
2 \\
3 \\
3 \\
2\end{array}$ & $\begin{array}{l}\text { Mannose } \\
\text { Cellobiose } \\
\text { Lactose } \\
\text { Sucrose } \\
\text { Maltose } \\
\text { Trehalose } \\
\text { Melezitose } \\
\text { Raffinose } \\
\text { Glycogen } \\
\text { Inulin } \\
\text { Amygdalin } \\
\text { Arbutin } \\
\text { Salicin } \\
\text { Adonitol } \\
\text { Dulcitol } \\
\text { Glycerol } \\
\text { Mannitol } \\
\text { Sorbitol } \\
\text { Inositol } \\
\text { Dextrin } \\
\text { Starch } \\
\text { Glucosamine } \\
\text { Sodium acetate } \\
\text { Sodium- } n \text {-butyrate } \\
\text { Sodium propionate } \\
\text { Sodium- } n \text {-octoate } \\
\text { Adipic acid } \\
\text { Pimelic acid } \\
\text { Sebacic acid } \\
\text { Sodium succinate } \\
\text { Sodium-H-malate } \\
\text { Sodium malonate } \\
\text { Sodium benzoate } \\
\text { Testosterone } \\
m \text {-Hydroxybenzoic acid } \\
p \text {-Hydroxybenzoic acid } \\
\text { L- } \alpha \text {-Alanine } \\
\text { D- } \alpha \text {-Alanine } \\
\text { DL-Nor-leucine } \\
\text { L-Threonine } \\
\text { L-Tryptophan } \\
\text { L-Tyrosine } \\
\text { I--Proline } \\
\text { Betaine HCl } \\
\text { Acetamide } \\
\text { Sodium lactate } \\
\text { Sodium tartrate } \\
\text { Sodium citrate } \\
\text { Sodium pyruvate } \\
\text { Benzamide } \\
\text { Sodium hippurate } \\
\text { Sodium gluconate } \\
\text { Protocatechuic acid } \\
\text { L-Serine } \\
p \text {-Cresol } \\
o \text {-Hydroxybenzaldehyde } \\
\text { D-Mandelic acid } \\
\text { Liquid paraffin } \\
\text { Lito }\end{array}$ & 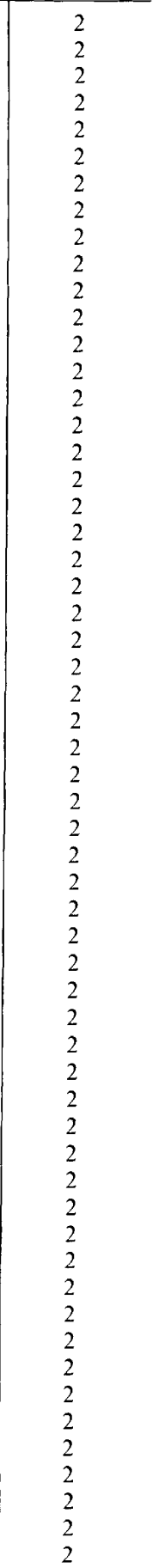 \\
\hline
\end{tabular}

${ }^{a}$ Multistate quantitative character. 
TABLE 3. Continued

\begin{tabular}{|c|c|c|c|}
\hline Characters & No. of states & Characters & No. of states \\
\hline $\begin{array}{l}\text { Utilization, as sole } \mathrm{C} \text { and } \mathrm{N} \text { source, of } \\
\text { Acetamide } \\
\text { Serine } \\
\text { Trimethyldiamine } \\
\text { Resistance to } \\
\text { Lysozyme } \\
\text { Penicillin } \\
\text { Bismith citrate }^{a} \\
\text { Crystal violet }^{a}\end{array}$ & $\begin{array}{l}2 \\
2 \\
4 \\
5\end{array}$ & $\begin{array}{l}\text { Phenol }^{a} \\
\text { Phenyl ethanol }^{a} \\
\text { Potassium tellurite }^{a} \\
\text { Sodium azide }^{a} \\
\text { Sodium chloride }^{a} \\
\text { Teepol }^{a} \\
\text { Tetrazolium }^{a} \\
\text { Thallous acetate }^{a} \\
\text { Thermotolerance }^{a} \\
\text { Acid tolerance }^{a}\end{array}$ & $\begin{array}{l}4 \\
5 \\
5 \\
5 \\
5 \\
4 \\
3 \\
4 \\
6 \\
6\end{array}$ \\
\hline
\end{tabular}

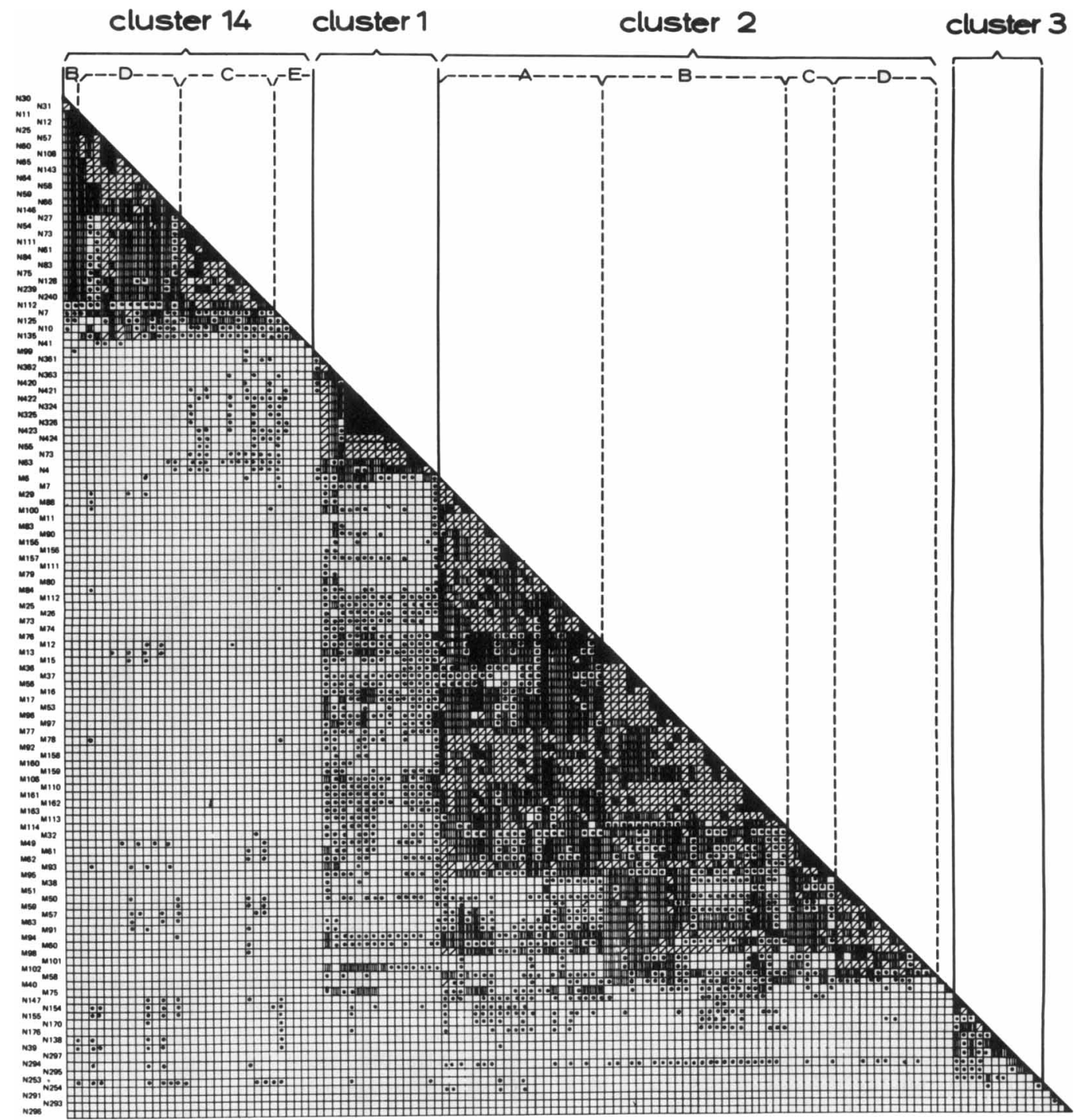

$100-90 \% \quad \square 90-85 \% \quad$ II $85-80 \% \quad \square 80-75 \%$

FIG. 1. Matching coefficient analysis. 


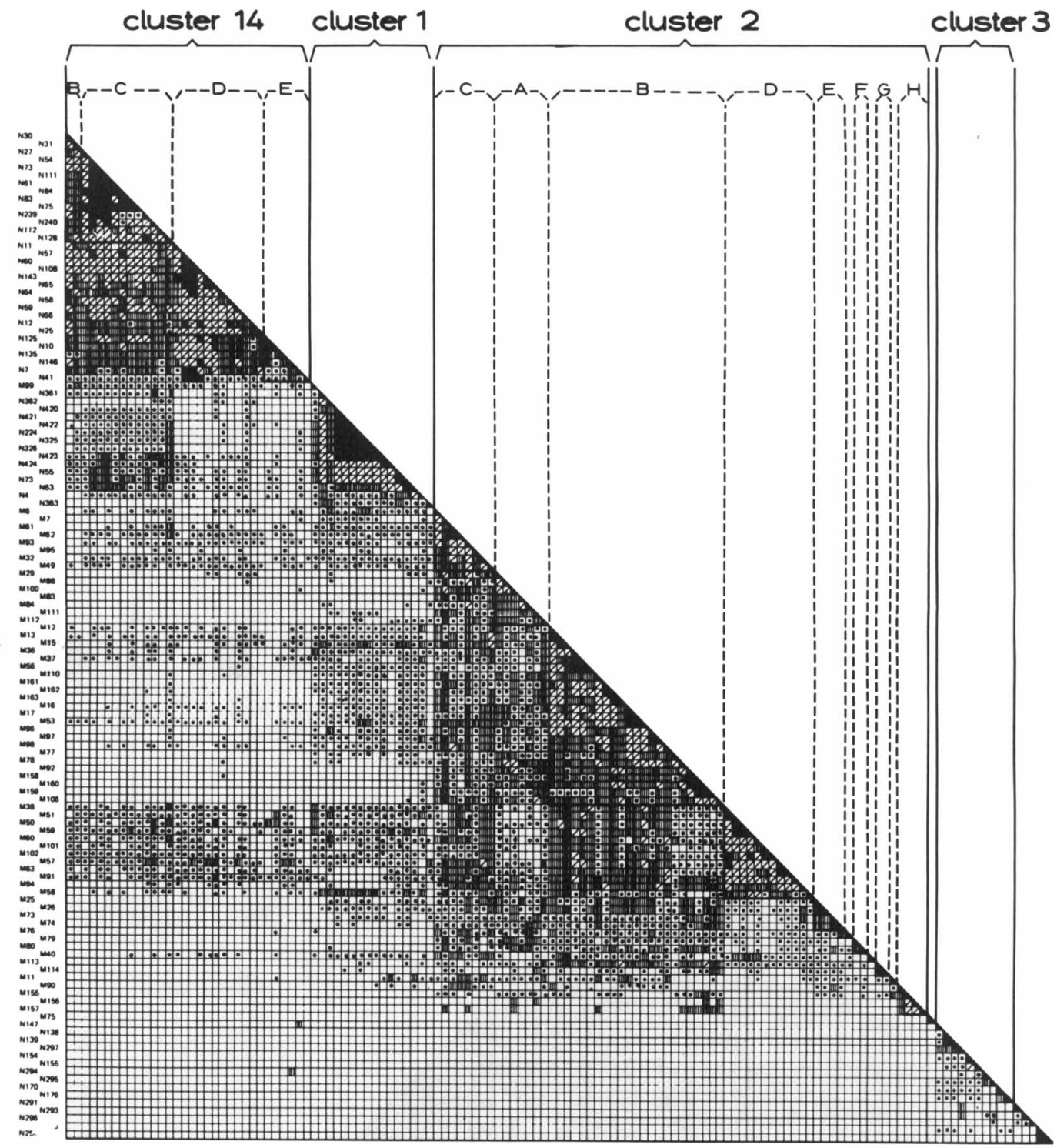

$100-80 \% \quad \square 80-70 \% \quad$ m $70-60 \% \quad \square 60-50 \%$

FIG. 2. Sorted similarity matrix.

20,40 , and 60 but not cellulose, chitin, gelatin, keratin, or xylan. They grow in the presence of $3 \%(\mathrm{w} / \mathrm{v}) \mathrm{NaCl}, 0.00001 \%(\mathrm{w} / \mathrm{v})$ crystal violet, $0.01 \%(\mathrm{w} / \mathrm{v})$ potassium tellurite, $0.001 \%(\mathrm{w} / \mathrm{v})$ sodium azide, and $0.001 \%(\mathrm{v} / \mathrm{v})$ teepol but are unable to use $\mathrm{D}$-arabinose, dulcitol, betaine, L-tryptophan, or serine as a sole source of carbon and energy. These tests had little discriminatory value and are omitted from further consideration.

The percentage frequency with each character was positive for the clusters shown in
Table 4. Although three of the clusters are homogeneous, few characters were found to be cluster specific. There is, however, sufficient consistency within clusters and differences between them for some characters to be weighted for identification. These characters were extracted from the data and used to construct a diagnostic table (Table 5). By using this table, strains of fast-growing mycobacteria can readily be separated from " $M$." rhodochrous strains.

Identification of subgroups. In the previous 


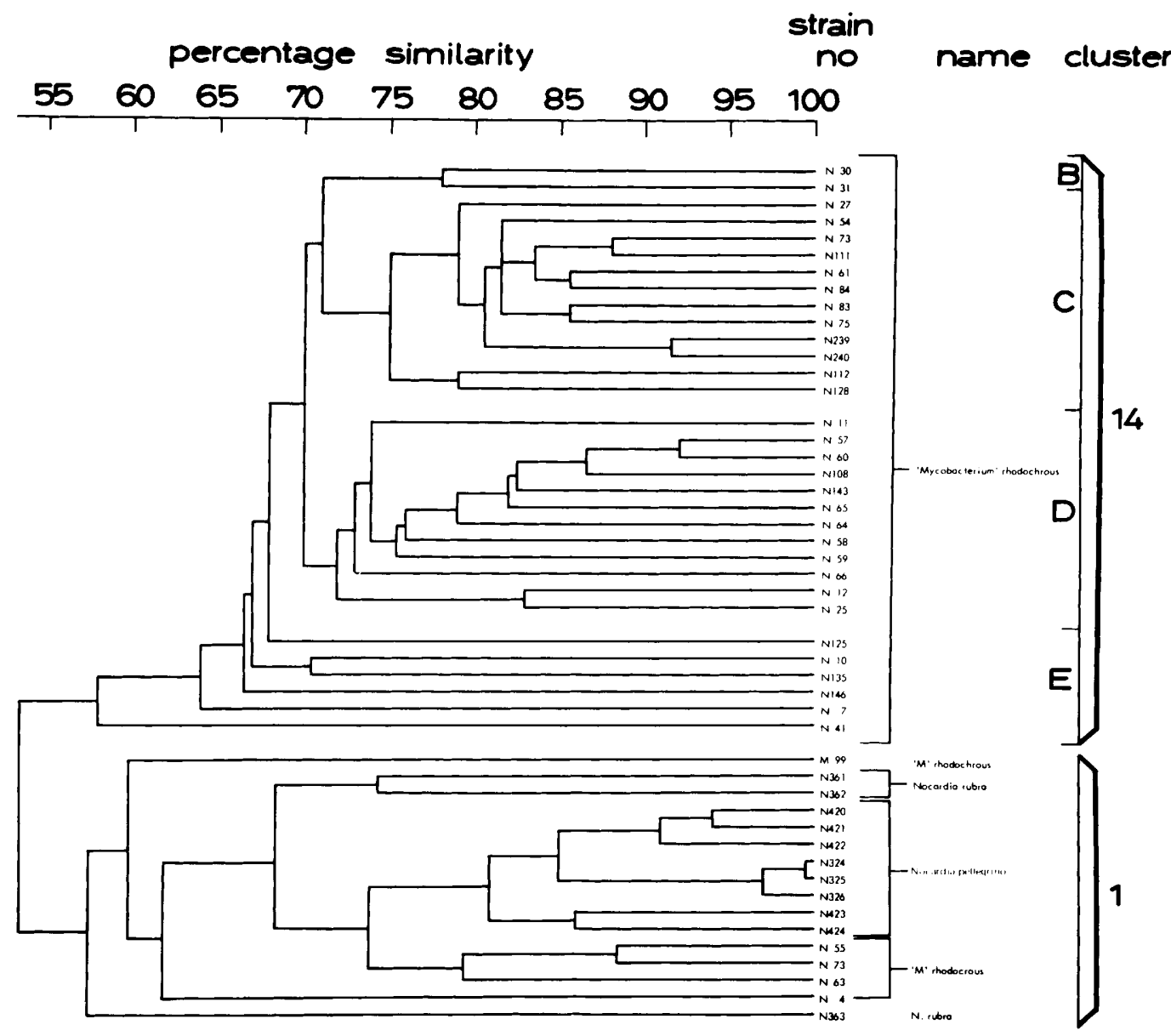

FIG. 3. Dendrogram derived by counting positive matches.

numerical analysis (6) the " $M$." rhodochrous subgroups $14 \mathrm{~A}$ to $14 \mathrm{E}$ were found to be sufficiently homogeneous for characters to be abstracted from the data and weighted for identification. Details on the properties of the subgroups and a diagnostic table for their differentiation can be found in the original paper. The properties of the subgroups of mycobacteria are shown in Table 6. Characters considered to have a presumptive diagnostic value were extracted from this table and weighted for identification (Table 7).

\section{DISCUSSION}

The numerical taxonomic evidence indicates that " $M$." rhodochrous strains form a recognizable taxon clearly separated from the genus
Mycobacterium as well as from Nocardia (6). Although similar findings were reported by Tsukamura (27), his inclusion of " $M$." rhodochrous in the newly proposed genus Gordona cannot be supported at present. Only six strains of " $M$." rhodochrous were examined by Tsukamura, and these are too few to reflect the range of variation of a taxon which is known to be heterogeneous $(6,7)$. On the other hand, data from pyrolysis gas chromatography led Lechevalier et al. (13) to propose that " $M$." rhodochrous be transferred to the genus Nocardia. Other lipid studies (14) show that nocardiae and " $M$." rhodochrous strains contain a lipid which appears to be specific for nocardiae. In some of the " $M$." rhodochrous strains, however, this characteristic lipid has a significantly lower $R_{F}$ value than that from the Nocardia asteroides reference strain. At the present time, therefore, there is insufficient 


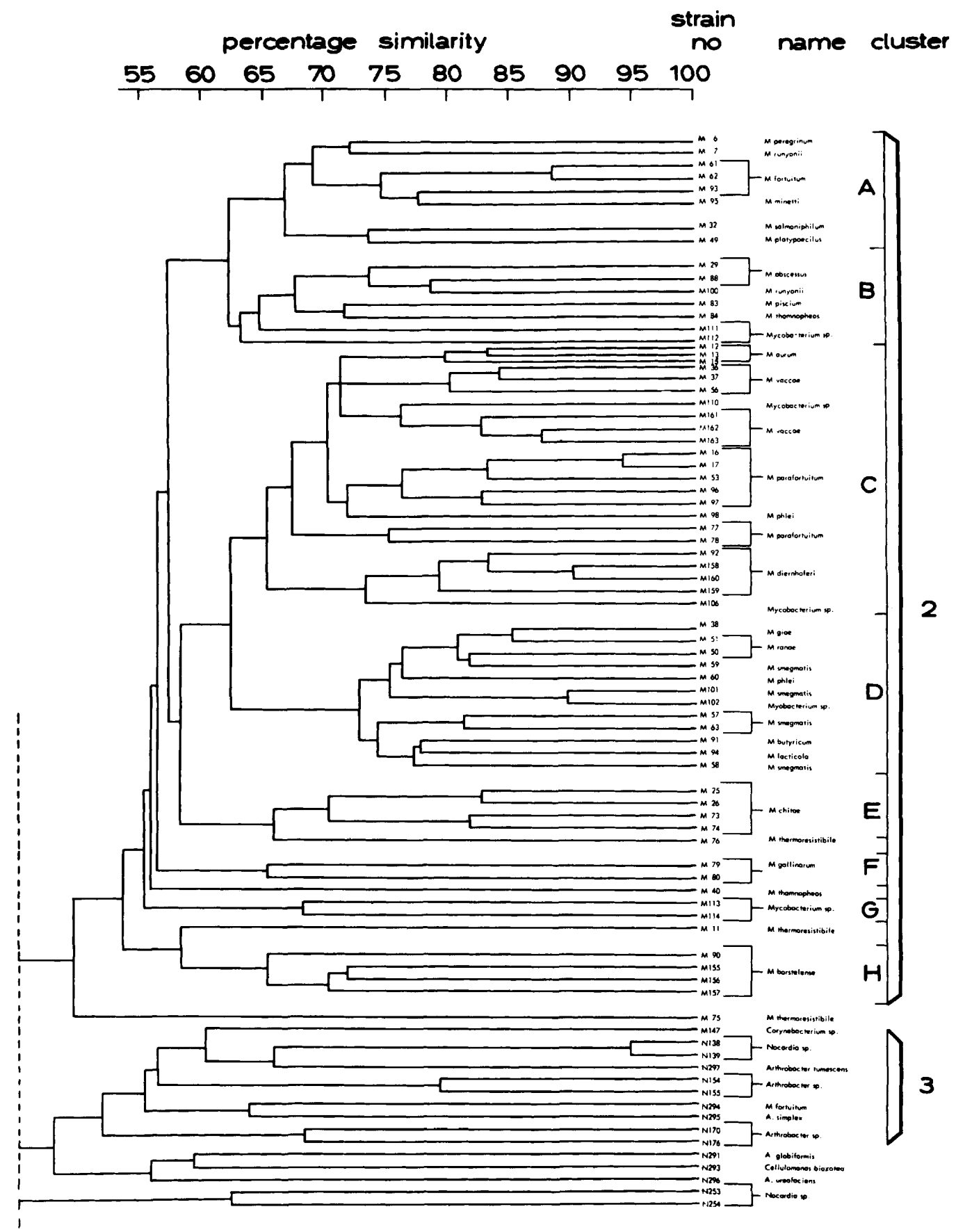

FIG. 4. Dendrogram derived by counting positive matches.

evidence for placing " $M$." rhodochrous in the genus Nocardia or in a new genus. A future generic assignment for this taxon should take into consideration the results of a subgroup which is working on these strains under the auspices of the International Working Group on Mycobacterial Taxonomy (IWGMT).

To date, there is no objective way of equating clusters or subgroups with orthodox taxonomic rank. Even so, it would appear from 
TABLE 4. Percentage frequency of positive characters found in the four clusters

\begin{tabular}{|c|c|c|c|c|}
\hline \multirow[t]{3}{*}{ Determination } & 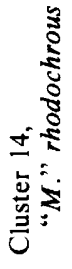 & 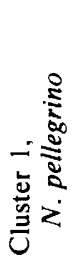 & 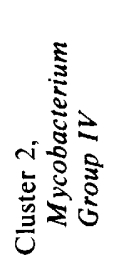 & 站 \\
\hline & \multicolumn{4}{|c|}{ No. of strains tested } \\
\hline & 32 & 16 & 64 & 10 \\
\hline$\ldots \ldots \ldots \ldots \ldots \ldots \ldots \ldots \ldots$ & 100 & 81 & 14 & 20 \\
\hline 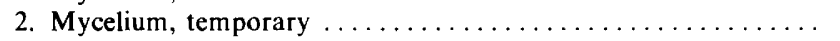 & 100 & 100 & 100 & 100 \\
\hline 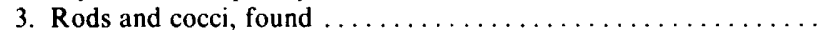 & 100 & 100 & 83 & 90 \\
\hline 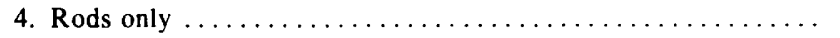 & 0 & 0 & 15 & 10 \\
\hline 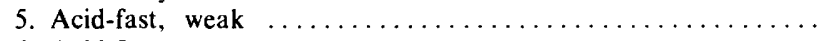 & 30 & 19 & 100 & 30 \\
\hline 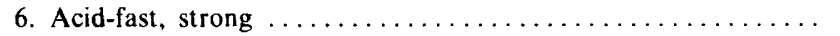 & 0 & 0 & 100 & 10 \\
\hline 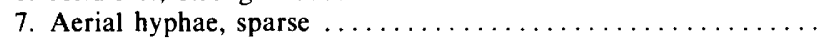 & 42 & 50 & 0 & 20 \\
\hline 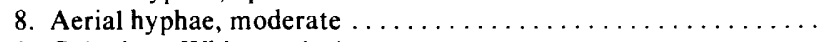 & 3 & 6 & 0 & 0 \\
\hline 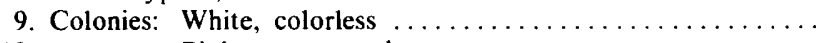 & 37 & 0 & 93 & 90 \\
\hline 10. Pink, orange, red $\ldots \ldots \ldots \ldots \ldots \ldots \ldots \ldots \ldots \ldots \ldots \ldots \ldots \ldots$ & 62 & 100 & 2 & 10 \\
\hline 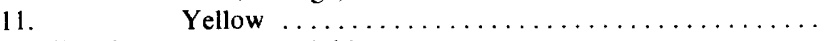 & 0 & 0 & 3 & 0 \\
\hline 12. Exopigment, water soluble $\ldots \ldots \ldots \ldots \ldots \ldots \ldots \ldots \ldots$ & 19 & 0 & 0 & 0 \\
\hline 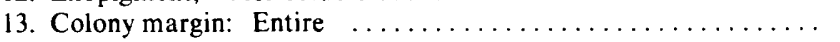 & 90 & 31 & 80 & 100 \\
\hline 14. $\quad$ Filamentous $\ldots \ldots \ldots \ldots \ldots \ldots \ldots \ldots$ & 13 & 68 & 17 & 0 \\
\hline Deeply filamentous $\ldots \ldots \ldots \ldots \ldots \ldots$ & 0 & 0 & 2 & 0 \\
\hline 16. Colonies easy to emulsify $\ldots \ldots \ldots \ldots \ldots \ldots \ldots \ldots \ldots \ldots \ldots \ldots \ldots \ldots \ldots \ldots \ldots \ldots$. & 100 & 100 & 83 & 100 \\
\hline 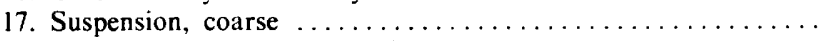 & 3 & 0 & 2 & 0 \\
\hline 18. Colony elevation: Flat/raised $\ldots \ldots \ldots \ldots \ldots \ldots \ldots \ldots \ldots \ldots \ldots \ldots \ldots \ldots \ldots \ldots$ & 19 & 50 & 14 & 0 \\
\hline 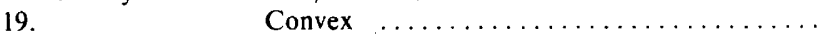 & 74 & 25 & 62 & 70 \\
\hline Irregular $\ldots \ldots \ldots \ldots \ldots \ldots \ldots \ldots \ldots \ldots \ldots \ldots \ldots \ldots$ & 9 & 25 & 23 & 30 \\
\hline \multicolumn{5}{|l|}{ Hydrolysis Tests } \\
\hline 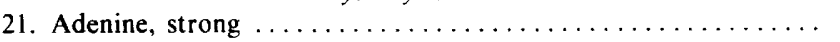 & 50 & 0 & 0 & 0 \\
\hline 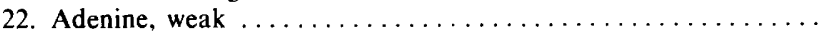 & 70 & 0 & 0 & 0 \\
\hline 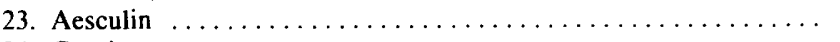 & 100 & 100 & 62 & 90 \\
\hline 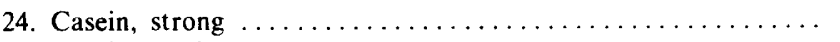 & 3 & 0 & 2 & 50 \\
\hline 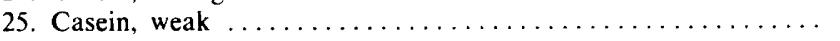 & 3 & 0 & 2 & 60 \\
\hline 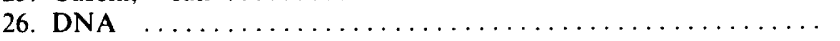 & 64 & 0 & 0 & 80 \\
\hline 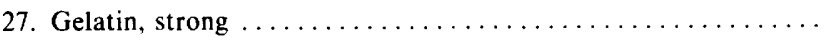 & 0 & 0 & 0 & 50 \\
\hline 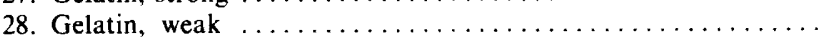 & 0 & 0 & 0 & 60 \\
\hline 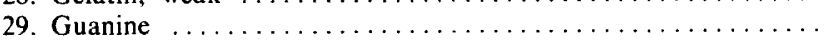 & 3 & 0 & 0 & 20 \\
\hline 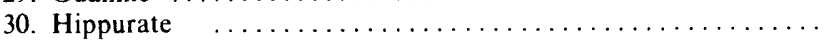 & 3 & 19 & 23 & 0 \\
\hline 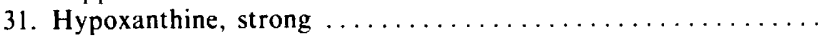 & 3 & 0 & 0 & 0 \\
\hline 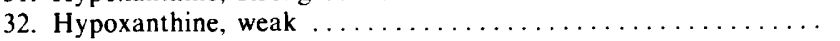 & 3 & 0 & 0 & 0 \\
\hline 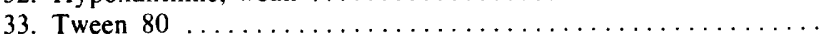 & 22 & 68 & 89 & 20 \\
\hline 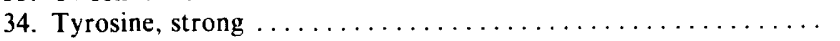 & 61 & 74 & 0 & 20 \\
\hline 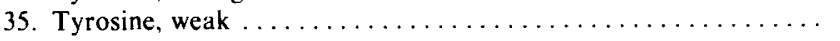 & 74 & 74 & 0 & 20 \\
\hline$\ldots \ldots \ldots \ldots \ldots \ldots \ldots \ldots \ldots$ & 3 & 0 & 0 & 0 \\
\hline 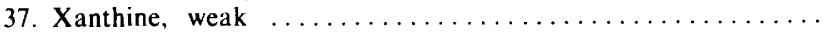 & 3 & 0 & 0 & 0 \\
\hline Sole Carbon Sources & & & & \\
\hline 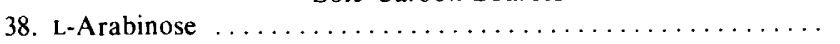 & 13 & 0 & 59 & 40 \\
\hline 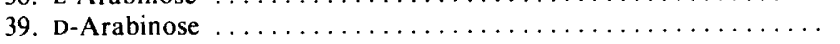 & 0 & 0 & 0 & 20 \\
\hline 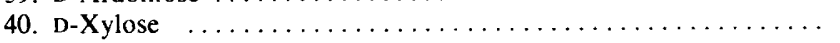 & 6 & 0 & 53 & 30 \\
\hline 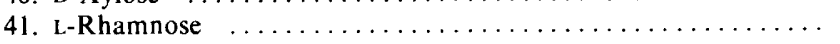 & 10 & 0 & 38 & 0 \\
\hline 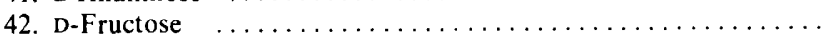 & 93 & 100 & 77 & 90 \\
\hline$\ldots \ldots \ldots \ldots \ldots \ldots$ & 45 & 0 & 21 & 30 \\
\hline 44. D-Glucose $\ldots \ldots$. & 100 & 100 & 97 & 100 \\
\hline 45. Mannose ........ & 100 & 100 & 80 & 80 \\
\hline 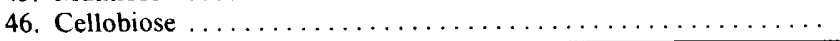 & 13 & 0 & 20 & 10 \\
\hline
\end{tabular}


TABLE 4. Continued

\begin{tabular}{|c|c|c|c|c|}
\hline \multirow[t]{3}{*}{ Determination } & 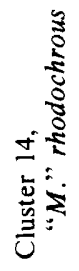 & 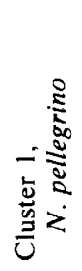 & 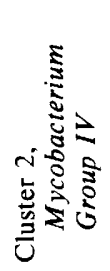 & है \\
\hline & \multicolumn{4}{|c|}{ No. of strains tested } \\
\hline & 32 & 16 & 64 & 10 \\
\hline 47. Lactose. & 6 & 0 & 2 & 30 \\
\hline 48. Sucrose & 84 & 56 & 34 & 30 \\
\hline 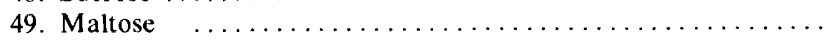 & 61 & 56 & 56 & 60 \\
\hline 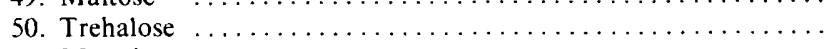 & 97 & 68 & 41 & 40 \\
\hline 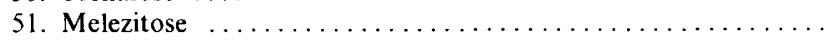 & 0 & 43 & 0 & 20 \\
\hline 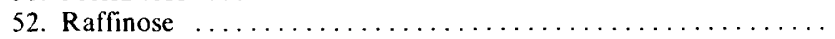 & 6 & 25 & 0 & 40 \\
\hline 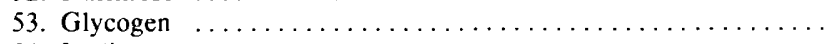 & 3 & 0 & 8 & 10 \\
\hline$\ldots \ldots \ldots \ldots \ldots \ldots \ldots$ & 93 & 100 & 42 & 0 \\
\hline 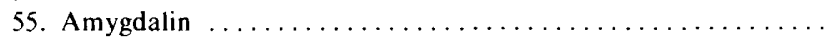 & 0 & 19 & 0 & 20 \\
\hline 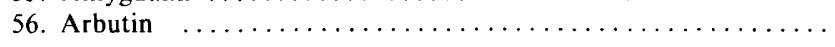 & 3 & 0 & 15 & 30 \\
\hline$\ldots \ldots \ldots \ldots \ldots \ldots \ldots \ldots \ldots \ldots \ldots \ldots$ & 42 & 0 & 0 & 0 \\
\hline 58. Adonitol $\ldots \ldots \ldots \ldots \ldots \ldots \ldots \ldots \ldots \ldots \ldots \ldots$ & 0 & 25 & 44 & 0 \\
\hline 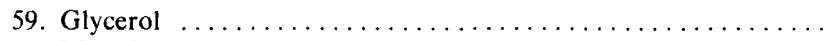 & 96 & 94 & 72 & 80 \\
\hline 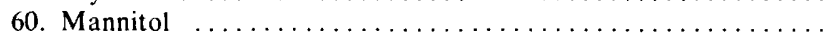 & 100 & 100 & 75 & 70 \\
\hline 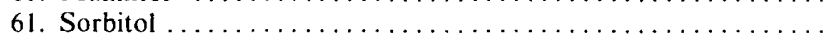 & 97 & 100 & 35 & 20 \\
\hline 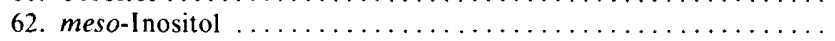 & 32 & 6 & 56 & 0 \\
\hline 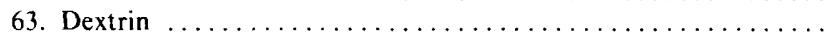 & 48 & 12 & 0 & 30 \\
\hline 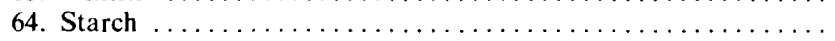 & 64 & 37 & 0 & 20 \\
\hline 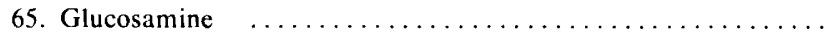 & 58 & 0 & 0 & 50 \\
\hline 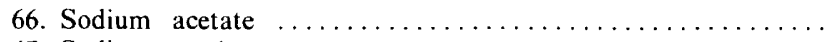 & 93 & 100 & 80 & 70 \\
\hline 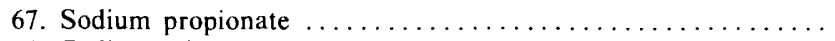 & 100 & 100 & 85 & 70 \\
\hline 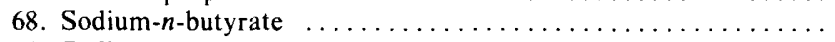 & 100 & 100 & 80 & 70 \\
\hline 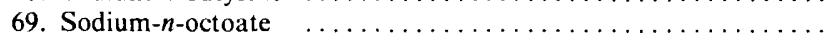 & 67 & 62 & 18 & 20 \\
\hline 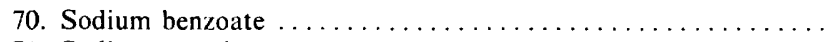 & 45 & 94 & 44 & 0 \\
\hline 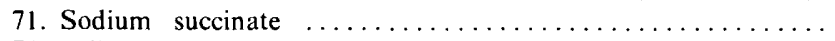 & 86 & 100 & 3 & 10 \\
\hline 72. Adipic acid $\ldots \ldots \ldots \ldots \ldots \ldots \ldots \ldots \ldots \ldots \ldots \ldots$ & 93 & 56 & 6 & 10 \\
\hline 73. Pimelic acid $\ldots \ldots \ldots \ldots \ldots \ldots \ldots \ldots \ldots \ldots \ldots \ldots \ldots$ & 67 & 0 & 0 & 30 \\
\hline 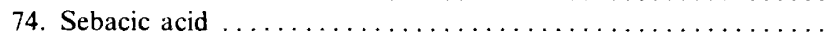 & 93 & 0 & 42 & 0 \\
\hline 75. Sodium lactate $\ldots \ldots \ldots \ldots \ldots \ldots \ldots \ldots \ldots \ldots \ldots$ & 96 & 68 & 36 & 0 \\
\hline 76. Sodium-H-malate $\ldots \ldots \ldots \ldots \ldots \ldots \ldots \ldots \ldots \ldots$ & 100 & 100 & 60 & 50 \\
\hline 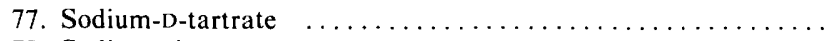 & 10 & 25 & 0 & 30 \\
\hline 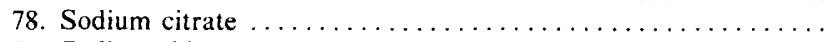 & 96 & 88 & 32 & 80 \\
\hline 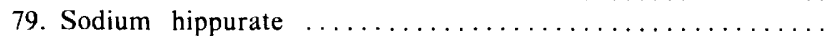 & 3 & 6 & 9 & 0 \\
\hline 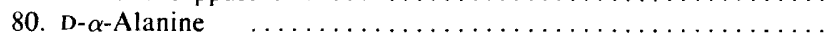 & 42 & 37 & 17 & 20 \\
\hline 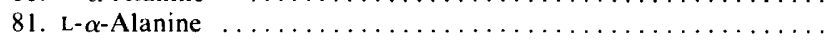 & 70 & 0 & 15 & 0 \\
\hline 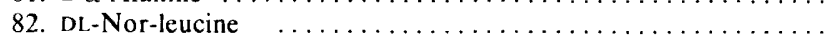 & 67 & 62 & 35 & 20 \\
\hline 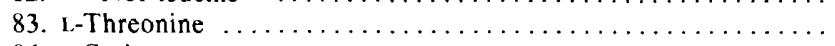 & 16 & 0 & 0 & 10 \\
\hline 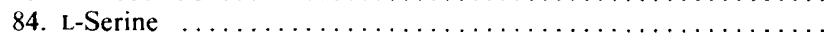 & 42 & 0 & 11 & 10 \\
\hline 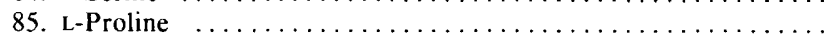 & 42 & 6 & 35 & 0 \\
\hline 86. L-Tyrosine & 52 & 94 & 0 & 20 \\
\hline 87. $p$-Hydroxybenzoic acid $\ldots \ldots \ldots \ldots \ldots \ldots \ldots \ldots$ & 80 & 81 & 0 & 0 \\
\hline$\ldots \ldots \ldots \ldots \ldots \ldots \ldots \ldots \ldots$ & 54 & 68 & 0 & 0 \\
\hline 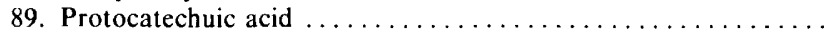 & 91 & 74 & 21 & 10 \\
\hline 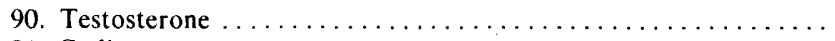 & 80 & 81 & 32 & 0 \\
\hline 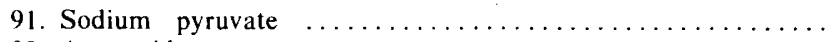 & 100 & 100 & 24 & 50 \\
\hline 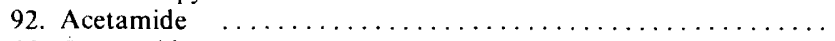 & 91 & 74 & 41 & 50 \\
\hline 93. Benzamide $\ldots \ldots \ldots \ldots \ldots \ldots \ldots \ldots$ & 19 & 6 & 23 & 0 \\
\hline 94. $p$-Cresol $\ldots \ldots \ldots$ & 54 & 0 & 0 & 0 \\
\hline 95. Paraffin & 100 & 62 & 0 & 80 \\
\hline 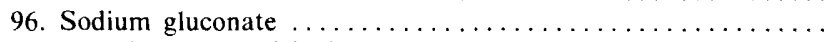 & 64 & 0 & 0 & 20 \\
\hline 97. $o$-Hydroxybenzaldehyde $\ldots \ldots \ldots \ldots \ldots \ldots \ldots \ldots \ldots$ & 42 & 12 & 2 & 0 \\
\hline
\end{tabular}


TABLE 4. Continued

\begin{tabular}{|c|c|c|c|c|}
\hline \multirow[t]{3}{*}{ Determination } & 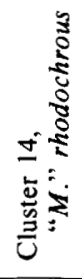 & 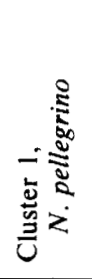 & 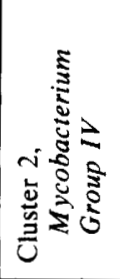 & है \\
\hline & \multicolumn{4}{|c|}{ No. of strains tested } \\
\hline & 32 & 16 & 64 & 10 \\
\hline 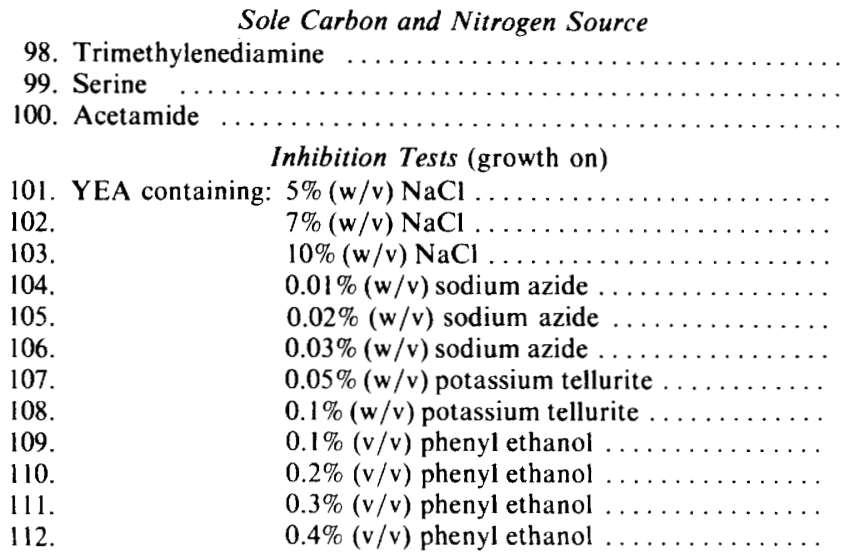 & $\begin{array}{r}100 \\
80 \\
16 \\
77 \\
50 \\
3 \\
86 \\
70 \\
100 \\
100 \\
80 \\
6\end{array}$ & $\begin{array}{r}62 \\
19 \\
0 \\
12 \\
6 \\
0 \\
94 \\
81 \\
88 \\
50 \\
12 \\
12\end{array}$ & $\begin{array}{r}47 \\
14 \\
3 \\
15 \\
5 \\
2 \\
97 \\
75 \\
97 \\
54 \\
8 \\
2\end{array}$ & $\begin{array}{r}100 \\
60 \\
20 \\
40 \\
20 \\
0 \\
30 \\
20 \\
100 \\
90 \\
50 \\
20\end{array}$ \\
\hline 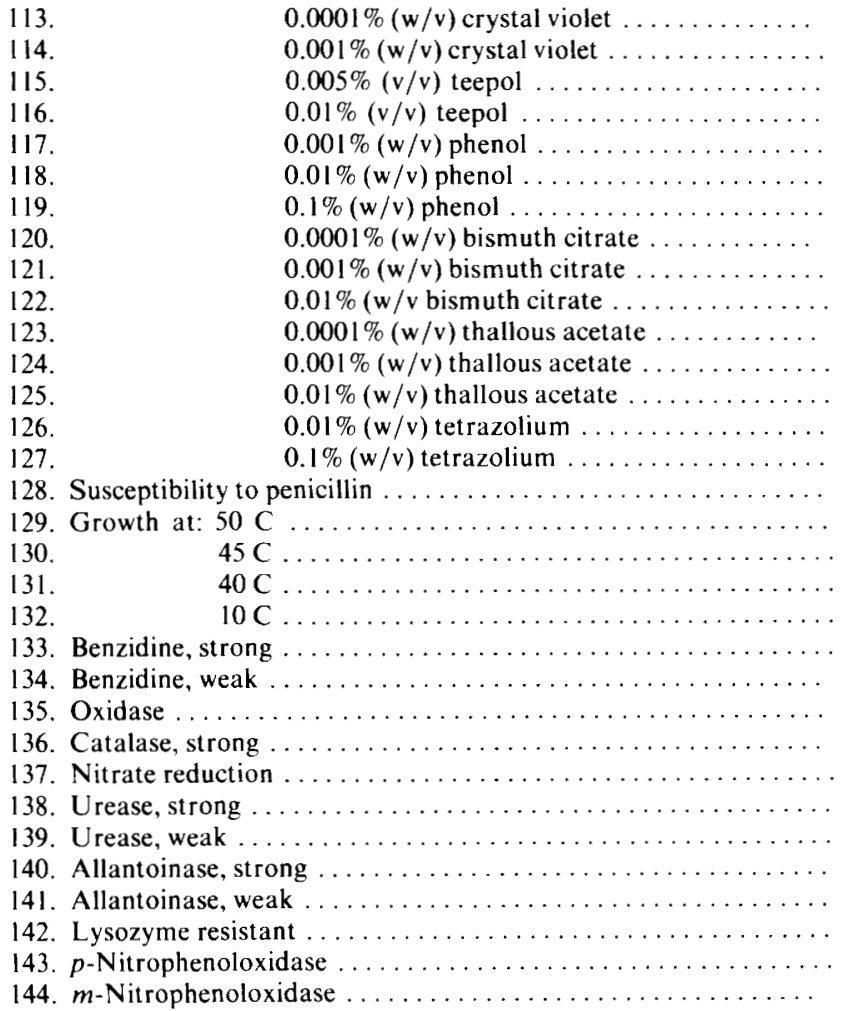 & $\begin{array}{r}50 \\
26 \\
100 \\
100 \\
100 \\
100 \\
64 \\
100 \\
100 \\
77 \\
100 \\
19 \\
0 \\
100 \\
0 \\
100 \\
3 \\
10 \\
100 \\
96 \\
100 \\
100 \\
0 \\
100 \\
100 \\
48 \\
54 \\
3 \\
42 \\
0 \\
10 \\
19\end{array}$ & $\begin{array}{r}94 \\
88 \\
100 \\
62 \\
100 \\
100 \\
62 \\
100 \\
74 \\
19 \\
100 \\
62 \\
25 \\
31 \\
0 \\
92 \\
0 \\
25 \\
88 \\
25 \\
88 \\
100 \\
0 \\
100 \\
62 \\
12 \\
12 \\
0 \\
0 \\
0 \\
0 \\
50\end{array}$ & $\begin{array}{r}100 \\
78 \\
96 \\
85 \\
97 \\
93 \\
9 \\
96 \\
87 \\
26 \\
98 \\
65 \\
30 \\
54 \\
15 \\
0 \\
0 \\
6 \\
44 \\
2 \\
33 \\
90 \\
0 \\
86 \\
75 \\
63 \\
66 \\
0 \\
0 \\
14 \\
2 \\
2\end{array}$ & $\begin{array}{r}40 \\
0 \\
80 \\
20 \\
100 \\
60 \\
20 \\
100 \\
40 \\
40 \\
100 \\
50 \\
0 \\
100 \\
0 \\
90 \\
0 \\
0 \\
40 \\
80 \\
50 \\
100 \\
10 \\
30 \\
80 \\
10 \\
20 \\
0 \\
0 \\
10 \\
0 \\
0\end{array}$ \\
\hline
\end{tabular}


TABLE 5. Characteristics of the clusters

\begin{tabular}{|c|c|c|c|c|}
\hline \multirow[t]{3}{*}{ Determination } & 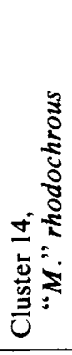 & 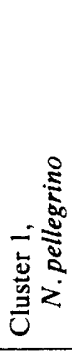 & 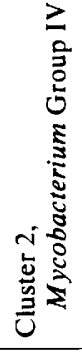 & 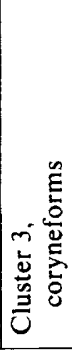 \\
\hline & \multicolumn{4}{|c|}{ No. of strains tested } \\
\hline & 32 & 16 & 64 & 10 \\
\hline 1. Mycelium, formed & $+^{a}$ & + & - & - \\
\hline 6. Acid-fast, strong . & - & - & + & - \\
\hline $\begin{array}{l}\text { 9. Colonies-white, } \\
\text { colorless ......... } \\
\text { Sole Carbon Sources }\end{array}$ & $v$ & - & + & + \\
\hline 54. Inulin $\ldots \ldots \ldots \ldots$ & + & + & v. & - \\
\hline 71. Sodium succinate .. & + & + & - & - \\
\hline 72. Adipic acid $\ldots \ldots$ & + & $\mathrm{v}$ & - & - \\
\hline 74. Sebacic acid .. & + & - & - & - \\
\hline 86. L-Tyrosine ... & $v$ & + & - & $v$ \\
\hline 95. Paraffin $\ldots$. & + & $\mathrm{v}$ & - & + \\
\hline 128. Susceptibility to & & & & \\
\hline penicillin $\ldots \ldots$ & + & + & - & + \\
\hline 132. Growth at $10 \mathrm{C}$ & + & $\mathrm{v}$ & - & + \\
\hline
\end{tabular}

${ }^{a}$ Plus $(+)$ or minus $(-)$ means that $85 \%$ or more of the strains give that result; $v$, variable, i.e., 16 to $84 \%$ of strains give a positive result.

the results of this work that too many species have been suggested for fast-growing mycobacteria. Some of the subgroups are homogeneous and can be compared to species even though they contain strains which belong to two or more named species. Subgroups based upon overall similarity are more reliable than taxa defined on a few properties, and they accommodate a degree of individual strain variability. It is doubtful, therefore, whether the differences between some of the taxa of mycobacteria are sufficient to consider the taxa as species.

Subgroup 2B is homogeneous and can probably be equated with a species. In this case $M$. aurum, $M$. diernhoferi and $M$. parafortuitum can be reduced to synonyms of $M$. vaccae, a name which has priority over the others. Additional evidence drawn from numerical taxonomy lends support to some of these proposals. Thus, although $M$. aurum and $M$. parafortuitum were described by Tsukamura $(23,24)$, he and his colleagues later included them in a single species, M. parafortuitum (28).
These workers also considered that the differences observed between $M$. diernhoferi and $M$. parafortuitum might be due solely to differences in the rates of growth of these organisms.

Subgroup $2 \mathrm{C}$ is equivalent to the established species $M$. fortuitum. This taxon includes the type strains of $M$. minetti, $M$. peregrinum, and M. salmoniphilum. Several workers have already considered $M$. minetti as belonging to $M$. fortuitum $(4,8,10,12,28)$, and Ross (16) was able to distinguish $M$. salmoniphilum from this species only by two characters.

Similarly, subgroup 2D can be considered equivalent to $M$. smegmatis, but this subgroup also contains strains named $M$. butyricum, $M$. lacticola, and strains mislabeled as $M$. ranae. Strains of these species have frequently been recognized as strains of $M$. smegmatis $(4,10$, 28 ). When positive matches only are counted, subgroup $2 \mathrm{~A}$ is recovered as a tight group containing strains named $M$. abscessus, $M$. piscium, and $M$. runyonii. Some of these strains share a high overall similarity with strains of $M$. fortuitum, from which they are difficult to distinguish. This result leaves the taxonomic state of $M$. abscessus ( $M$. runyonii) confused, for, while. Tsukamura $(28,29)$ reduced the name $M$. abscessus to a synonym of $M$. fortuitum, Nagayama et al. (15) regarded $M$. abscessus as a separate species. In the second analysis, $M$. borstelense, $M$. chitae, and $M$. gallinarum fell into subgroups which were separate both from one another and from subgroup $2 \mathrm{~A}$. This result supports the finding that $M$. abscessus and $M$. borstelense are distinct species (26), though data from lipid and serological tests have led to the recommendation that $M$. borstelense be recognized as a subspecies of $M$. abscessus (11). The strains in these subgroups are relatively slow growers, and cluster formation may have been influenced by this factor. Although these subgroups probably represent distinct species, the degree of varia. tion between them should be separated into the two components of vigor and pattern (19) to ensure that this is so.

It was possible to weight characters for the identification of clusters and for the subgroups of mycobacteria. In particular, strains of " $M$." rhodochrous can now be readily separated from fast-growing mycobacteria. In addition to classical tests, such as the degree of acid-fastness, some of the newly applied characters were found to have a differential value. Some of the carbon compounds used as sole sources of carbon and energy are prominent in the diagnostic tables. It was, however, found that 


\begin{tabular}{|c|c|c|c|c|c|c|c|c|}
\hline \multirow{4}{*}{ Determination } & \multicolumn{8}{|c|}{ Subgroup } \\
\hline & $2 \mathrm{~A}$ & $2 \mathbf{B}$ & $2 \mathrm{C}$ & $2 \mathrm{D}$ & $2 \mathrm{E}$ & $2 \mathrm{~F}$ & $2 \mathrm{G}$ & $2 \mathrm{H}$ \\
\hline & \multicolumn{8}{|c|}{ No. of strains tested } \\
\hline & 7 & 23 & 8 & 12 & 4 & 2 & 2 & 4 \\
\hline 1. Mycelium, formed & 0 & 0 & 62 & 25 & 0 & 0 & 0 & 0 \\
\hline 2. Mycelium, temporary & 0 & 0 & 100 & 100 & 0 & 0 & 0 & 0 \\
\hline 3. Rods and cocci, formed & 56 & 100 & 75 & 83 & 100 & 100 & 100 & 100 \\
\hline 4. Rods, only $\ldots \ldots \ldots$ & 43 & 0 & 25 & 17 & 0 & 0 & 0 & 0 \\
\hline 9. Colonies: White, colorless & 100 & 82 & 100 & 92 & 100 & 100 & 0 & 100 \\
\hline 10. Orange, pink, red & 0 & 0 & 0 & 8 & 0 & 0 & 100 & 0 \\
\hline Yellow ......... & 0 & 10 & 0 & 0 & 0 & 0 & 0 & 0 \\
\hline 13. Colony margin: Entire $\ldots \ldots \ldots \ldots \ldots \ldots \ldots \ldots \ldots \ldots \ldots \ldots \ldots \ldots \ldots \ldots$ & 84 & 100 & 62 & 50 & 50 & 100 & 0 & 100 \\
\hline 14. Filamentous $\ldots \ldots \ldots \ldots \ldots \ldots \ldots \ldots$ & 0 & 0 & 38 & 50 & 50 & 0 & 100 & 0 \\
\hline Deeply filamentous $\ldots \ldots \ldots \ldots \ldots \ldots$ & 14 & 0 & 0 & 0 & 0 & 0 & 0 & 0 \\
\hline 16. Colonies easy to emulsify $\ldots \ldots \ldots \ldots \ldots \ldots \ldots \ldots \ldots \ldots \ldots \ldots \ldots \ldots$ & 100 & 91 & 0 & 100 & 100 & 100 & 100 & 100 \\
\hline 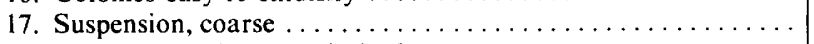 & 14 & 0 & 0 & 0 & 0 & 0 & 0 & 0 \\
\hline 18. Colony elevation: Flat/raised & 0 & 13 & 12 & 50 & 0 & 0 & 0 & 0 \\
\hline $19 . \quad$ Convex .. & 84 & 84 & 25 & 8 & 100 & 50 & 50 & 100 \\
\hline $\begin{array}{l}\text { Irregular } \quad \ldots \ldots \ldots \ldots \ldots \ldots \ldots \ldots \ldots \\
\text { Hydrolysis Tests }\end{array}$ & 14 & 4 & 62 & 42 & 0 & 50 & 50 & 0 \\
\hline 23. Aesculin & 100 & 53 & 88 & 58 & 100 & 100 & 0 & 100 \\
\hline 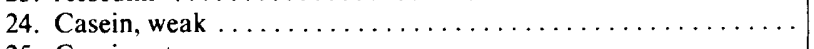 & 0 & 0 & 0 & 0 & 25 & 0 & 0 & 0 \\
\hline$\ldots \ldots \ldots \ldots \ldots \ldots \ldots \ldots \ldots \ldots \ldots \ldots \ldots$ & 0 & 0 & 0 & 0 & 25 & 0 & 0 & 0 \\
\hline$\ldots \ldots \ldots \ldots \ldots \ldots \ldots$ & 28 & 40 & 0 & 8 & 0 & 100 & 0 & 0 \\
\hline 33. Tween, $80 \ldots$ & 56 & 100 & 88 & 92 & 100 & 100 & 100 & 100 \\
\hline Sole Carbon Source & & & & & & & & \\
\hline 38. L-Arabinose & 0 & 88 & 12 & 92 & 0 & 100 & 100 & 0 \\
\hline 40. D-Xy & 14 & 88 & 0 & 92 & 0 & 0 & 50 & 0 \\
\hline 41. L-R hamnose .. & 42 & 65 & 0 & 100 & 0 & 0 & 100 & 0 \\
\hline 42. D-Fructose & 0 & 100 & 100 & 100 & 100 & 50 & 0 & 0 \\
\hline 43. D-Galactose & 0 & 0 & 12 & 92 & 0 & 0 & 0 & 0 \\
\hline 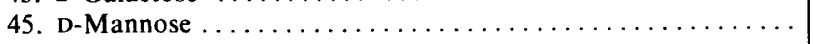 & 84 & 93 & 100 & 100 & 0 & 50 & 50 & 100 \\
\hline 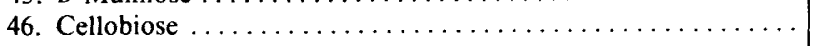 & 0 & 22 & 12 & 42 & 0 & 0 & 0 & 0 \\
\hline 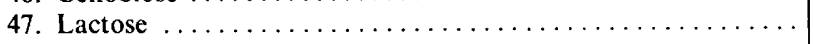 & 0 & 0 & 0 & 8 & 0 & 0 & 0 & 0 \\
\hline 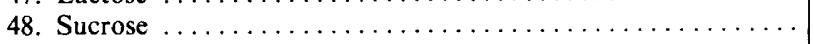 & 0 & 69 & 0 & 50 & 0 & 0 & 0 & 0 \\
\hline 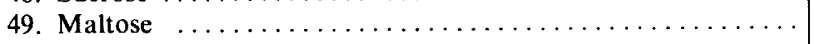 & 0 & 65 & 75 & 92 & 25 & 50 & 0 & 25 \\
\hline 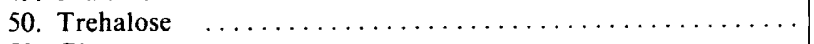 & 0 & 65 & 25 & 75 & 0 & 0 & 50 & 0 \\
\hline 53. Glycogen . . . . . . . . . . & 0 & 0 & 0 & 34 & 0 & 0 & 0 & 0 \\
\hline 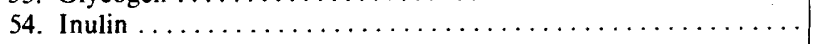 & 0 & 61 & 25 & 75 & 50 & 0 & 0 & 0 \\
\hline 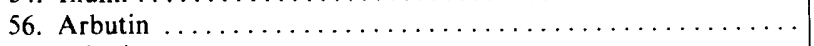 & 28 & 0 & 38 & 25 & 0 & 0 & 0 & 0 \\
\hline 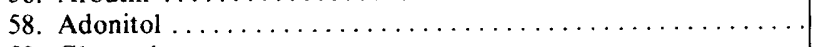 & 0 & 88 & 0 & 92 & 25 & 0 & 0 & 0 \\
\hline$\ldots \ldots \ldots \ldots \ldots \ldots$ & 70 & 88 & 100 & 100 & 0 & 100 & 0 & 0 \\
\hline 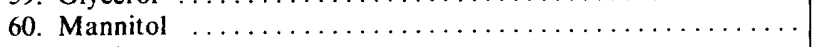 & 14 & 91 & 62 & 92 & 100 & 100 & 100 & 0 \\
\hline 61. Sorbitol ........... & 28 & 26 & 0 & 92 & 0 & 50 & 0 & 0 \\
\hline 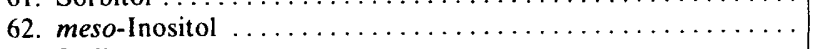 & 0 & 88 & 12 & 92 & 100 & 100 & 50 & 0 \\
\hline 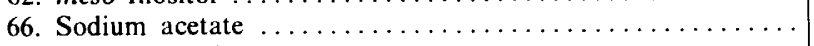 & 84 & 88 & 100 & 92 & 100 & 100 & 0 & 0 \\
\hline 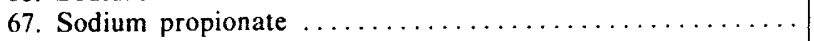 & 70 & 96 & 100 & 100 & 100 & 0 & 50 & 0 \\
\hline 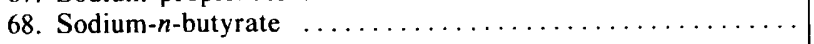 & 42 & 84 & 100 & 100 & 50 & 50 & 100 & 50 \\
\hline 69. Sodium-n-octoate .. & 14 & 4 & 50 & 58 & 0 & 0 & 50 & 0 \\
\hline 70. Sodium benzoate . . . . . . . . & 14 & 53 & 0 & 92 & 100 & 0 & 100 & 0 \\
\hline 71. Sodium succinate $\ldots \ldots \ldots \ldots$ & 0 & 0 & 12 & 0 & 0 & 0 & 0 & 0 \\
\hline 72. Adipic acid ....... & 0 & 0 & 50 & 0 & 0 & 0 & 0 & 0 \\
\hline 74. Sebacic acid & 28 & 22 & 88 & 100 & 0 & 0 & 0 & 0 \\
\hline 75. Sodium lactate & 14 & 35 & 38 & 66 & 100 & 0 & 0 & 0 \\
\hline 76. Sodium-H-malate & 0 & 78 & 88 & 92 & 0 & 0 & 0 & 0 \\
\hline 78. Sodium citrate ... & 0 & 50 & 62 & 66 & 0 & 0 & 0 & 25 \\
\hline 79. Sodium hippurate. & 0 & 0 & 0 & 17 & 0 & 0 & 0 & 0 \\
\hline 80. D- $\alpha$-Alanine $\ldots \ldots$ & 0 & 0 & 25 & 58 & 0 & 0 & 0 & 0 \\
\hline 81. DL-Nor-leucine & 14 & 31 & 88 & 42 & 0 & 0 & 0 & 0 \\
\hline 82. L- $\alpha$-Alanine . & 0 & 13 & 25 & 42 & 0 & 0 & 0 & 0 \\
\hline
\end{tabular}




\begin{tabular}{|c|c|c|c|c|c|c|c|c|}
\hline \multirow{4}{*}{ Determination } & \multicolumn{8}{|c|}{ Subgroup } \\
\hline & $2 \mathrm{~A}$ & $2 \mathrm{~B}$ & $2 \mathrm{C}$ & 2D & $2 \mathrm{E}$ & $2 \mathrm{~F}$ & $2 \mathrm{G}$ & $2 \mathrm{H}$ \\
\hline & \multicolumn{8}{|c|}{ No. of strains tested } \\
\hline & 7 & 23 & 8 & 12 & 4 & 2 & 2 & 4 \\
\hline 84. L-Serine & 0 & 9 & 12 & 32 & 0 & 0 & 0 & 0 \\
\hline 85. L-Proline & 0 & 18 & 75 & 92 & 0 & 0 & 0 & 0 \\
\hline 89. Protocatechuic acid & 14 & 31 & 0 & 58 & 0 & 0 & 0 & 0 \\
\hline 90. Testosterone ...... & 28 & 40 & 88 & 8 & 0 & 0 & 0 & 0 \\
\hline 91. Sodium pyruvate. & 0 & 26 & 0 & 75 & 0 & 0 & 0 & 0 \\
\hline 92. Acetamide .... & 0 & 22 & 75 & 100 & 50 & 0 & 0 & 0 \\
\hline 93. Benzamide & 14 & 22 & 0 & 62 & 0 & 0 & 50 & 0 \\
\hline 97. o-Hydroxybenzaldehyde . & 0 & 0 & 0 & 8 & 0 & 0 & 0 & 0 \\
\hline \multicolumn{9}{|l|}{ Sole Carbon and Nitrogen Source } \\
\hline 99. Trimethylenediamine $\ldots \ldots \ldots \ldots \ldots \ldots$ & 7 & 0 & 0 & 0 & 0 & 0 & 0 & 0 \\
\hline 99. Serine & 0 & 0 & 0 & 8 & 0 & 0 & 0 & 0 \\
\hline 100. Acetamide $\ldots$. & 0 & 0 & 50 & 8 & 50 & 0 & 0 & 0 \\
\hline \multicolumn{9}{|l|}{ Inhibition Tests (growth on) } \\
\hline 101. YEA containing: $5 \%(\mathrm{w} / \mathrm{v}) \mathrm{NaCl} \ldots \ldots$ & 56 & 26 & 62 & 100 & 75 & 50 & 0 & 25 \\
\hline 102. $7 \%(w / v) \mathrm{NaCl}$ & 14 & 9 & 12 & 42 & 25 & 0 & 0 & 0 \\
\hline $10 \%(\mathrm{w} / \mathrm{v}) \mathrm{NaCl}$ & 0 & 4 & 0 & 0 & 0 & 0 & 0 & 0 \\
\hline $0.01 \%(\mathrm{w} / \mathrm{v})$ Sodium azide $\ldots \ldots \ldots \ldots$ & 28 & 9 & 25 & 32 & 0 & 50 & 100 & 0 \\
\hline $0.02 \%(\mathrm{w} / \mathrm{v})$ Sodium azide $\ldots \ldots \ldots \ldots$ & 0 & 4 & 25 & 0 & 0 & 0 & 0 & 0 \\
\hline $0.03 \%(w / v)$ Sodium azide & 0 & 0 & 12 & 0 & 0 & 0 & 0 & 0 \\
\hline $0.05 \%(w / v)$ Potassium tellurite $\ldots \ldots \ldots$ & 84 & 100 & 100 & 100 & 100 & 100 & 100 & 100 \\
\hline $0.1 \%(\mathrm{w} / \mathrm{v})$ Potassium tellurite $\ldots \ldots \ldots$ & 56 & 100 & 100 & 83 & 100 & 50 & 100 & 100 \\
\hline $0.1 \%(v / v)$ Phenyl ethanol $\ldots \ldots \ldots \ldots$ & 100 & 100 & 100 & 100 & 50 & 100 & 100 & 100 \\
\hline $0.2 \%(\mathrm{v} / \mathrm{v})$ Phenyl ethanol $\ldots \ldots \ldots \ldots$ & 42 & 53 & 62 & 100 & 0 & 50 & 0 & 50 \\
\hline $0.3 \%(\mathrm{v} / \mathrm{v})$ Phenyl ethanol $\ldots \ldots \ldots \ldots$ & 0 & 4 & 0 & 42 & 0 & 0 & 0 & 0 \\
\hline $0.4 \%(\mathrm{v} / \mathrm{v})$ Phenyl ethanol $\ldots \ldots \ldots \ldots$ & 0 & 0 & 0 & 8 & 0 & 0 & 0 & 0 \\
\hline $0.001 \%(\mathrm{w} / \mathrm{v})$ Crystal violet ......... & 100 & 85 & 100 & 92 & 100 & 50 & 0 & 50 \\
\hline $0.005 \%(\mathrm{v} / \mathrm{v})$ Teepol $\ldots . .$. & 100 & 91 & 100 & 100 & 100 & 100 & 100 & 100 \\
\hline $0.01 \%(\mathrm{v} / \mathrm{v})$ Teepol & 70 & 85 & 88 & 100 & 0 & 100 & 100 & 100 \\
\hline $0.001 \%(\mathrm{v} / \mathrm{v})$ Phenol $\ldots \ldots \ldots \ldots \ldots \ldots$ & 100 & 100 & 100 & 100 & 100 & 100 & 100 & 100 \\
\hline $0.01 \%(w / v)$ Phenol $\ldots \ldots \ldots \ldots \ldots \ldots$ & 100 & 100 & 100 & 100 & 100 & 100 & 50 & 25 \\
\hline $0.1 \%(w / v)$ Phenol. & 0 & 0 & 0 & 58 & 0 & 0 & 0 & 0 \\
\hline $0.0001 \%(w / v)$ Bismuth citrate $\ldots \ldots \ldots \ldots$ & 100 & 100 & 100 & 100 & 100 & 100 & 100 & 25 \\
\hline $0.001 \%(\mathrm{w} / \mathrm{v})$ Bismuth citrate $\ldots \ldots \ldots \ldots$ & 100 & 96 & 100 & 100 & 100 & 100 & 100 & 0 \\
\hline $0.01 \%(\mathrm{w} / \mathrm{v})$ Bismuth citrate $\ldots \ldots$ & 56 & 0 & 50 & 58 & 0 & 100 & 0 & 0 \\
\hline $0.0001 \%(\mathrm{w} / \mathrm{v})$ Thallous acetate $\ldots$. & 100 & 100 & 100 & 100 & 100 & 100 & 100 & 75 \\
\hline $0.001 \%(\mathrm{w} / \mathrm{v})$ Thallous acetate $\ldots \ldots$ & 70 & 100 & 100 & 83 & 50 & 100 & 0 & 25 \\
\hline $0.01 \%(\mathrm{w} / \mathrm{v})$ Thallous acetate. & 56 & 44 & 88 & 17 & 0 & 100 & 0 & 0 \\
\hline $0.01 \%(w / v)$ Tetrazolium . . . . . . . . . . & 100 & 44 & 75 & 92 & 25 & 50 & 0 & 0 \\
\hline $0.1 \%(\mathrm{w} / \mathrm{v})$ Tetrazolium $\ldots \ldots \ldots \ldots \ldots$ & 53 & 0 & 12 & 50 & 0 & 0 & 0 & 0 \\
\hline \multicolumn{9}{|l|}{ Growth at (temp) } \\
\hline 130. $45 \mathrm{C}$ & 0 & 0 & 0 & 50 & 0 & 0 & 0 & 0 \\
\hline $131.40 \mathrm{C} \ldots \ldots \ldots$ & 56 & 31 & 50 & 92 & 100 & 0 & 0 & 0 \\
\hline 132. $10 \mathrm{C} \ldots \ldots \ldots$ & 14 & 0 & 0 & 0 & 0 & 0 & 0 & 0 \\
\hline \multicolumn{9}{|l|}{ Biochemical Tests } \\
\hline 133. Benzidine & 0 & 17 & 62 & 100 & 0 & 0 & 50 & 0 \\
\hline 134. Benzidine, weak. & 100 & 91 & 100 & 100 & 100 & 0 & 100 & 100 \\
\hline 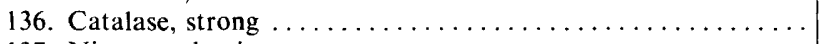 & 100 & 84 & 88 & 92 & 100 & 100 & 50 & 100 \\
\hline 137. Nitrate reduction $\ldots \ldots \ldots \ldots \ldots \ldots \ldots \ldots \ldots \ldots \ldots \ldots \ldots \ldots \ldots \ldots \ldots \ldots \ldots$ & 70 & 70 & 100 & 83 & 50 & 100 & 50 & 100 \\
\hline 138. Urease, strong ... & 56 & 91 & 75 & 100 & 0 & 100 & 0 & 25 \\
\hline 139. Urease, weak . . & 56 & 91 & 75 & 100 & 0 & 100 & 50 & 25 \\
\hline 142. Lysozyme resistant & 56 & 0 & 50 & 0 & 0 & 0 & 0 & 0 \\
\hline 143. $p$-Nitrophenoloxidase & 0 & 0 & 12 & 0 & 0 & 0 & 0 & 0 \\
\hline 144. $m$-Nitrophenoloxidase $\ldots \ldots$ & 0 & 4 & 0 & 0 & 0 & 0 & 0 & 0 \\
\hline
\end{tabular}


TABLE 7. Characteristics of the subgroups of "Mycobacterium"

\begin{tabular}{|c|c|c|c|c|c|c|c|c|}
\hline \multirow{4}{*}{ Determination } & \multicolumn{8}{|c|}{ Subgroup } \\
\hline & $2 \mathrm{~A}$ & 2B & $2 \mathrm{C}$ & $2 \mathrm{D}$ & $2 \mathrm{E}$ & $2 F$ & $2 \mathrm{G}$ & $2 \mathrm{H}$ \\
\hline & \multicolumn{8}{|c|}{ No. of strains tested } \\
\hline & 7 & 23 & 8 & 12 & 4 & 2 & 2 & 4 \\
\hline 9. Colonies: White, colorless & $+^{a}$ & + & + & + & + & + & - & + \\
\hline 10. Orange, pink, red & - & - & - & - & - & - & + & - \\
\hline 30. Hydrolysis of hippurate $\ldots \ldots \ldots \ldots \ldots \ldots$ & $\mathbf{v}$ & $\mathrm{v}$ & - & - & - & + & - & - \\
\hline Sole Carbon Source & & & & & & & & \\
\hline 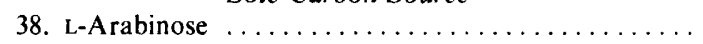 & - & + & - & + & - & + & + & - \\
\hline 40. D-Xylose $\ldots \ldots \ldots \ldots \ldots \ldots \ldots \ldots \ldots$ & - & + & - & + & - & - & $\mathrm{v}$ & - \\
\hline 41. L-Rhamnose $\ldots \ldots \ldots \ldots \ldots \ldots \ldots \ldots \ldots \ldots$ & $\mathrm{v}$ & $\mathrm{v}$ & - & + & - & - & + & - \\
\hline 42. D-Fructose $\ldots \ldots \ldots \ldots \ldots \ldots \ldots \ldots \ldots \ldots \ldots \ldots \ldots \ldots \ldots \ldots$ & - & + & + & + & + & $\mathrm{v}$ & - & - \\
\hline 43. D-Galactose .......... & - & - & - & + & - & - & - & - \\
\hline 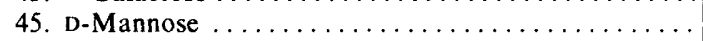 & + & + & + & + & - & $\mathbf{v}$ & v & + \\
\hline 58. Adonitol $\ldots \ldots \ldots \ldots \ldots \ldots \ldots \ldots \ldots \ldots \ldots \ldots$ & - & + & - & + & $\mathrm{v}$ & - & - & - \\
\hline 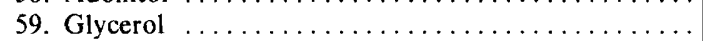 & $\mathrm{v}$ & + & + & + & - & + & - & - \\
\hline 60. Mannitol $\ldots \ldots \ldots \ldots \ldots \ldots \ldots \ldots \ldots \ldots \ldots$ & - & + & $\mathrm{v}$ & + & + & + & + & - \\
\hline 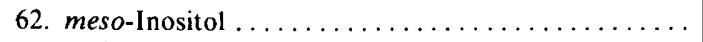 & - & + & - & + & + & + & $\mathrm{v}$ & - \\
\hline 66. Sodium acetate $\ldots \ldots \ldots \ldots \ldots \ldots \ldots \ldots$ & + & + & + & + & + & + & - & - \\
\hline 67. Sodium propionate $\ldots \ldots \ldots \ldots \ldots \ldots \ldots$ & $\mathrm{v}$ & + & + & + & + & - & $\mathrm{v}$ & - \\
\hline 70. Sodium benzoate . ....... & - & $v$ & - & + & + & - & + & - \\
\hline 74. Sebacic acid $\ldots \ldots \ldots \ldots \ldots \ldots \ldots$ & $\mathrm{v}$ & $v$ & + & + & - & - & - & - \\
\hline 76. Sodium-H-malate . . . . & - & $\mathrm{v}$ & + & + & - & - & - & - \\
\hline 90. Testosterone $\ldots \ldots \ldots \ldots$ & $\mathrm{v}$ & $\mathrm{v}$ & + & - & - & - & - & - \\
\hline 131. Growth at $40 \mathrm{C} \ldots \ldots \ldots \ldots \ldots$ & $\mathrm{v}$ & $v$ & $\mathrm{v}$ & + & + & - & - & - \\
\hline 139. Urease, weak ........ & $\mathrm{v}$ & + & $v$ & + & - & + & $v$ & $\mathrm{v}$ \\
\hline
\end{tabular}

${ }^{a}$ Plus (+) or minus (-) means that $85 \%$ or more of the strains give that result; $v$, variable, i.e., 16 to $84 \%$ of strains give a positive result.

the results of some tests did not always correspond with those obtained by other workers $(11,15,27,28)$. At present, little work has been done to assess the reproducibility of simple phenotypic characters considered to have a diagnostic value. Now that several large recognizable groups of nocardiae and mycobacteria are emerging, the search for reliable diagnostic characters can be intensified.

\section{ACKNOWLEDGMENTS}

This investigation was supported, in part, by Medical Research Council grant G970/112/B.

We thank P. H. A. Sneath for valuable discussions at all stages of the work. We are grateful to Grace Hedley for her help and also to many colleagues for providing the cultures used in this study.

\section{LITERATURE CITED}

1. Bönicke, R., and S. E. Juhasz. 1964. Beschreibung der neuen Species Mycobacterium vaccae, n. sp. Zentralbl. Bakteriol. Parasitenk. Abt. Orig. 192:133-135.

2. Bönicke, R., and S. E. Juhasz. 1965. Mycobac- terium diernhoferi, n. sp., eine in der Umgebung des Rindes häufig vorkommende neue Mycobacterium-Species. Zentralbl. Bakteriol. Parasitenk. Abt. Orig. 197:292-294.

3. Bönicke, R., and D. Stottmeier. 1965. Erkennung und Identifizierung von Stämmen der Species Mycobacterium borstelense. Beitr. Klin. Tuberk. Bd. 130:210-222.

4. Cerbón, J., and L. F. Bojalil. 1961. Physiological relationships of rapidly growing mycobacteria. $\mathbf{J}$. Gen. Microbiol. 25:7-15.

5. Goodfellow, M. 1969. Numerical taxonomy of some heterotrophic bacteria isolated from a pine forest soil, p. 83-105. In J. G. Sheals (ed.), The soil ecosystem. Systematics Association Publication No. 8.

6. Goodfellow, M. 1971. Numerical taxonomy of some nocardioform bacteria. J. Gen. Microbiol. 69:33-80.

7. Gordon, R. E. 1966. Some strains in search of a genus-Corynebacterium, Mycobacterium, Nocardia or what? J. Gen. Microbiol. 43:329-343.

8. Gordon, R. E., and J. M. Mihm. 1957. A comparative study of some strains received as nocardiae. $J$. Bacteriol. 73:15-27.

9. Gordon, R. E., and J. M. Mihm. 1959. A comparison of four species of mycobacteria. J. Gen. Microbiol. 21:736-748.

10. Gordon, R. E., and M. M. Smith. 1953. Rapidly 
growing, acid fast bacteria. 1. Species' descriptions of Mycobacterium phlei Lehmann and Neumann and Mycobacterium smegmatis (Trevisan) Lehmann and Neumann. J. Bacteriol. 66:41-47.

11. Jenkins, P. A., J. Marks, and W. B. Schaefer. 1971. Lipid chromatography and seroagglutination in the classification of rapidly growing mycobacteria. Amer. Rev. Resp. Dis. 103:179-187.

12. Käppler, W. 1968. Zur Taxonomie der Gattung Mycobacterium. 1. Klassifizierung schnell wachsender Mykobakterien. Z. Tuberk. 129:311-319.

13. Lechevalier, M. P., A. C. Horan, and H. Lechevalier. 1971. Lipid composition in the classification of nocardiae and mycobacteria. J. Bacteriol. 105:313-318.

14. Mordarska, H., M. Mordarski, and M. Goodfellow. 1972. Chemotaxonomic characters and classification of some nocardioform bacteria. J. Gen. Microbiol. 71:77-87.

15. Nakayama, Y., H. Nakayama, and K. Takeya. 1970. Studies of the relationship between $\mathrm{Myco}$ bacterium fortuitum and Mycobacterium runyonii. Amer. Rev. Resp. Dis. 101:558-568.

16. Ross, A. J. 1960. Mycobacterium salmoniphilum sp. nov. from salmonoid fishes. Amer. Rev. Resp. Dis. 81:241-250.

17. Runyon, E. H. 1955. Veterans AdministrationNational Tuberculosis Association Cooperative Study of Mycobacteria. Amer. Rev. Resp. Dis. 72:866-868.
18. Sneath, P. H. A. 1957. The application of computers to taxonomy. J. Gen. Microbiol. 17:201-226.

19. Sneath, P. H. A. 1968. Vigour and pattern in taxonomy. J. Gen. Microbiol. 54:1-11.

20. Sneath, P. H. A., and M. Stevens. 1967. A divided petri dish for use with multipoint inoculators. J. Appl. Bacteriol. 30:495-497.

21. Sokal, R. R., and C. D. Michener. 1958. A statistical method for evaluating systematic relationships. Kans. Univ. Sci. Bull. 38: 1409-1438.

22. Sokal, R. R., and P. H. A. Sneath. 1963. Principles of numerical taxonomy. W. H. Freeman and Co., San Fransisco.

23. Tsukamura, M. 1966. Mycobacterium parafortuitum: a new species. J. Gen. Microbiol. 42:7-12.

24. Tsukamura, M. 1966. Adansonian classification of my cobacteria. J. Gen. Microbiol. 45:253-273.

25. Tsukamura, M. 1967. Mycobacterium chitae: a new species. Jap. J. Microbiol. 11:43-47.

26. Tsukamura, M. 1970. Differentiation between Mycobacterium abscessus and Mycobacterium borstelense. Amer. Rev. Resp. Dis. 101:426-428.

27. Tsukamura, M. 1971. Proposal of a new genus, Gordona, for slightly acid-fast organisms occurring in sputa of patients with pulmonary disease and in soil. J. Gen. Microbiol. 66:15-26.

28. Tsukamura, M., S. Mizuno, and S. Tsukamura. 1968. Classification of rapidly growing mycobacteria. Jap. J. Microbiol. 12:151-166.

29. Tsukamura, M., S. Tsukamura, and S. Mizuno. 1967. Numerical taxonomy of Mycobacterium fortuitum. Jap. J. Microbiol. 11:243-252. 